\title{
QUESTIONS
}

P1a In adult or pediatric patients affected by malignant hematological diseases who are candidate for autologous BMT

Interventions

P1c In adult or pediatric patients affected by malignant hematological diseases who are candidate for autologous BMT

Interventions

P1d In adult or pediatric patients affected by nonmalignant hematological diseases who are candidate for allogeneic BMT

Interventions

P2a In adult patients who undergo bone marrow transplantation

Interventions

P2b In pediatric patients who undergo bone marrow transplantation

Interventions
Outcomes:

Influence RR/AR

Detection of circulant HBV DNA or HCV RNA (vs HV genoma not detectable)

Detection of latent HBV infection (HBsAg+; HBVDNA-) (vs no latent HBV)

Detection of occult HBV infection (HBsAg-; HBVDNA-; Ac anti HBcAg+) (vs no occult HBV)

Detection of coagulative defect at baseline (vs no coag defects)

Increased liver stiffness (Fibroscan) at baseline (vs fibroscan F0)

Outcomes:

Influence RR/AR

Detection of circulant HBV DNA or HCV RNA (vs HV genoma not detectable)

Detection of latent HBV infection (HBsAg+; HBVDNA-) (vs no latent HBV)

Detection of occult HBV infection (HBsAg-; HBVDNA-; Ac anti HBcAg+) (vs no occult HBV)

Detection of coagulative defect at baseline (vs no coag defects)

Increased liver stiffness (Fibroscan) at baseline (vs fibroscan F0)

Outcomes:

\section{Reduce RR/AR}

Detection of circulant HBV DNA or HCV RNA (vs HV genoma not detectable)

Detection of latent HBV infection (HBsAg+; HBVDNA-) (vs no latent HBV)

Detection of occult HBV infection (HBsAg-; HBVDNA-; Ac anti HBcAg+) (vs no occult HBV)

Increased liver stiffness (Fibroscan) at baseline (vs fibroscan FO)

\section{Outcomes:}

\section{-Reduce RR/AR}

-NNT

Specific antiviral treatment/prophylaxis (vs no specific intervention)

Changes in conditioning regimen (ie, administering Cyclophosphamide BEFORE Busulfan) (vs no specific intervention)

Outcomes:

\section{-Reduce RR/AR}

-NNT

Specific antiviral treatment/prophylaxis (vs no specific intervention)

Changes in conditioning regimen (i.e. administering Cyclophosphamide BEFORE Busulfan)( vs no specific intervention) 


\section{P3a In patients characterized by the presence of at least 1 identified risk} factor for VOD

\section{Interventions}

D1a In adult patients subjected to bone marrow transplantation $<21 \mathrm{~d}$ after BMT

Interventions

D1b In pediatric patients subjected to bone marrow transplantation $<21 \mathrm{~d}$ after BMT

\section{Interventions}

D1c In adult or pediatric patients subjected to bone marrow transplantation $>21 \mathrm{~d}$ after BMT

\section{Interventions}

\section{Outcomes:}

-Reduce RR/AR

\section{NNT}

Administration of Ursodesoxycolic acid (vs no specific intervention)

Administration of defibrotide (low dosage) (vs no specific intervention)

Administration of heparin (vs no specific intervention)

\section{Outcomes:}

-Increase likelihood/ratio

-Diagnostic thresholds

Painful hepatomegaly (vs no painful hepatomegaly)

Detection of abnormal liver and kidney function test values (vs normal test values)

Weight gain (vs stable weight)

Oliguria/anuria (vs production of normal amounts of urine)

Increased liver stiffness (Fibroscan) (vs F0 Fibroscan (no fibrosis))

Persistence of thrombocytopenia after PLT transfusion (vs normal increase of platelets

number after PLT transfusion)

-Increase likelihood/ratio

-Diagnostic thresholds

Painful hepatomegaly (vs no painful hepatomegaly)

Detection of abnormal liver and kidney function test values (vs normal test values)

Weight gain (vs stable weight)

Oliguria/anuria (vs production of normal amounts of urine)

Alteration in tests exploring coagulation and/or thrombocytopenia (vs normal tests)

Persistence of thrombocytopenia after PLT transfusion (vs normal increase of platelets number after PLT transfusion)

Outcomes:

-Increase likelihood/ratio

-Diagnostic thresholds

Painful hepatomegaly (vs no painful hepatomegaly)

Detection of abnormal liver and kidney function test values (vs normal test values)

Weight gain (vs stable weight)

Oliguria/anuria (vs production of normal amounts of urine)

Increased liver stiffness (Fibroscan) (vs F0 Fibroscan (no fibrosis))

Alteration in tests exploring coagulation and/or thrombocytopenia (vs normal tests) 


\begin{tabular}{|c|c|}
\hline & $\begin{array}{l}\text { Persistence of thrombocytopenia after PLT transfusion (vs normal increase of platelets } \\
\text { number after PLT transfusion) }\end{array}$ \\
\hline D2a In adult patients with suspected VOD within 21 days after HCT & $\begin{array}{l}\text { Outcomes: } \\
\text {-Increase likelihood/ratio } \\
\text {-Diagnostic thresholds } \\
\text {-Effectiveness of diagnostic tests to impact relevant clinical outcomes } \\
\text {-Cost-Effectiveness/ratio }\end{array}$ \\
\hline \multirow[t]{11}{*}{ Interventions } & Seattle Criteria fulfilled (vs Seattle Criteria NOT fulfilled) \\
\hline & Baltimore Criteria Fulfilled (vs Baltimore Criteria NOT Fulfilled) \\
\hline & EBMT Criteria fulfilled (vs EBMT Criteria NOT fulfilled) \\
\hline & Hyperbilirubinemia (vs normal serum bilirubin) \\
\hline & Unexplained weight increase (vs stable weight) \\
\hline & Presence of edema and/or ascites (vs no evidence of vol. loss in the $3^{\circ}$ space) \\
\hline & Liver biopsy (vs no liver biopsy) \\
\hline & $\begin{array}{l}\text { Hepatomegaly and/or ascites evidence on the abdominal ultrasonography (vs lack of } \\
\text { hepatomegaly and/or ascites evidence on US) }\end{array}$ \\
\hline & $\begin{array}{l}\text { Decrease in velocity or reversal of the portal flow on the Doppler ultrasonography (vs no } \\
\text { imaging technique) }\end{array}$ \\
\hline & Computerized tomography scans (vs no imaging techniques) \\
\hline & $\begin{array}{l}\text { Measurement of the hepatic venous gradient pressure (HVGP) } \\
\text { (vs no specific intervention) }\end{array}$ \\
\hline D2b In adult patients with suspected VOD beyond 21 days after HCT & $\begin{array}{l}\text { Outcomes: } \\
\text {-Increase likelihood/ratio } \\
\text {-Diagnostic thresholds } \\
\text {-Effectiveness of diagnostic tests to impact relevant clinical outcomes } \\
\text {-Cost-Effectiveness/ratio }\end{array}$ \\
\hline \multirow[t]{7}{*}{ Interventions } & Seattle Criteria fulfilled (vs Seattle Criteria NOT fulfilled) \\
\hline & Baltimore Criteria Fulfilled (vs Baltimore Criteria NOT Fulfilled) \\
\hline & EBMT Criteria fulfilled (vs EBMT Criteria NOT fulfilled) \\
\hline & Hyperbilirubinemia (vs normal serum bilirubin) \\
\hline & Unexplained weight increase (vs stable weight) \\
\hline & Presence of edema and/or ascites (vs no evidence of volume loss in the third space) \\
\hline & Liver biopsy (vs no liver biopsy) \\
\hline
\end{tabular}




\begin{tabular}{|c|c|}
\hline & $\begin{array}{l}\text { Hepatomegaly and/or ascites evidence on the abdominal ultrasonography (vs lack of } \\
\text { hepatomegaly and/or ascites evidence on US) }\end{array}$ \\
\hline & $\begin{array}{l}\text { Decrease in velocity or reversal of the portal flow on the Doppler ultrasonography (vs no } \\
\text { imaging technique) }\end{array}$ \\
\hline & Computerized tomography scans (vs no imaging techniques) \\
\hline & Measurement of the hepatic venous gradient pressure (HVGP)(vs no specific intervention) \\
\hline D2c In pediatric patients with suspected VOD & $\begin{array}{l}\text { Outcomes: } \\
\text {-Increase likelihood/ratio } \\
\text {-Diagnostic thresholds } \\
\text {-Effectiveness of diagnostic tests to impact relevant clinical outcomes } \\
\text {-Cost-Effectiveness/ratio }\end{array}$ \\
\hline Interventions & Seattle Criteria fulfilled (vs Seattle Criteria NOT fulfilled) \\
\hline & Baltimore Criteria Fulfilled (vs Baltimore Criteria NOT Fulfilled) \\
\hline & EBMT Criteria fulfilled (vs EBMT Criteria NOT fulfilled) \\
\hline & Hyperbilirubinemia (vs normal serum bilirubin) \\
\hline & Unexplained weight increase (vs stable weight) \\
\hline & Painful hepatomegaly (vs no painful hepatomegaly) \\
\hline & Presence of edema and/or ascites (vs no evidence of volume loss in the third space) \\
\hline & Liver biopsy (vs no liver biopsy) \\
\hline & $\begin{array}{l}\text { Hepatomegaly and/or ascites evidence on the abdominal ultrasonography (vs lack of } \\
\text { hepatomegaly and/or ascites evidence on US) }\end{array}$ \\
\hline & $\begin{array}{l}\text { Decrease in velocity or reversal of the portal flow on the Doppler ultrasonography (vs no } \\
\text { imaging technique) }\end{array}$ \\
\hline & MRI (vs no imagine technique) \\
\hline & Measurement of the hepatic venous gradient pressure (HVGP) (vs no specific intervention) \\
\hline & Early thrombocytopenia (vs not early thrombocytopenia) \\
\hline D3a In adult patients with diagnosis of VOD & $\begin{array}{l}\text { Outcomes: } \\
\text {-Relative risk of mortality } \\
\text {-Relative risk of multiple organ failure } \\
\text {-Relative risk of terminal impairment of liver function } \\
\text {-Relative risk of need of ventilatory support or dialysis }\end{array}$ \\
\hline Intervention & $\begin{array}{l}\text { Fulfilment of EBMT criteria for Severe/Very Severe VOD grade (vs Fulfilment of EBMT criteria } \\
\text { for Mild/Moderate VOD grade) }\end{array}$ \\
\hline
\end{tabular}




\begin{tabular}{|c|c|}
\hline D3b In pediatric patients with diagnosis of VOD & $\begin{array}{l}\text { Outcomes: } \\
\text {-Relative risk of mortality } \\
\text {-Relative risk of multiple organ failure } \\
\text {-Relative risk of terminal impairment of liver function } \\
\text {-Relative risk of need of ventilatory support or dialysis } \\
\end{array}$ \\
\hline Intervention & $\begin{array}{l}\text { Fulfilment of EBMT criteria for Severe/Very Severe VOD grade (vs Fulfilment of EBMT criteria } \\
\text { for Mild/Moderate VOD grade) }\end{array}$ \\
\hline $\begin{array}{l}\text { T1a In adult patients with diagnosis of mild VOD according to EBMT criteria } \\
\text { for severity grading }\end{array}$ & $\begin{array}{l}\text { Outcomes: } \\
\text {-Reduction of relative and/or absolute risk for multiple organ failure } \\
\text {-NNT to prevent multiple organ failure } \\
\text {-Reduction of mortality related to veno-occlusive disease } \\
\text {-Reduction of risk of bleeding } \\
\text {-Reduction in supportive care needs (inotropic agents, diuretics, oxygen) } \\
\text {-Reduction of weight gain } \\
\text {-Absolute and relative risk of adverse effects and number needed to harm } \\
\text {-Normalization of ultrasound parameters } \\
\text {-Increase of platelets levels }\end{array}$ \\
\hline \multirow[t]{2}{*}{ Interventions } & Defibrotide vs no specific intervention \\
\hline & Ursodeoxycholic acid (UDCA) vs no specific intervention \\
\hline $\begin{array}{l}\text { T1c In adult or pediatric patients with diagnosis of severe VOD according to } \\
\text { EBMT criteria for severity grading }\end{array}$ & $\begin{array}{l}\text { Outcomes } \\
\text {-Reduction of relative and/or absolute risk for multiple organ failure } \\
\text {-NNT to prevent multiple organ failure } \\
\text {-Reduction of mortality related to veno-occlusive disease } \\
\text {-Reduction of risk of bleeding } \\
\text {-Reduction in supportive care needs (inotropic agents, diuretics, oxygen) } \\
\text {-Reduction of weight gain } \\
\text {-Absolute and relative risk of adverse effects and number needed to harm } \\
\text {-Normalization of ultrasound parameters } \\
\text {-Increase of platelets levels }\end{array}$ \\
\hline \multirow[t]{2}{*}{ Interventions } & Defibrotide vs no specific intervention \\
\hline & Ursodeoxycholic acid (UDCA) vs no specific intervention \\
\hline $\begin{array}{l}\text { T2a In adult or pediatric patients with diagnosis of mild VOD according to } \\
\text { EBMT criteria for severity grading }\end{array}$ & $\begin{array}{l}\text { Outcomes: } \\
\text {-Reduction of relative and/or absolute risk for multiple organ failure } \\
\text {-NNT to prevent multiple organ failure } \\
\text {-Reduction of mortality related to veno-occlusive disease } \\
\text {-Reduction of risk of bleeding } \\
\text {-Pain reduction }\end{array}$ \\
\hline
\end{tabular}


Interventions

T2b In adult or pediatric patients with diagnosis of moderate VOD according to EBMT criteria for severity grading

\section{Interventions}

T2c In adult or pediatric patients with diagnosis of severe VOD according to EBMT criteria for severity grading
Infusion of albumin (vs no specific intervention)

Transfusion of red blood cells with higher $\mathrm{Hb}$ target than usual (vs no specific intervention)

Analgesic therapy (vs no specific intervention)

Assessment of pain through the use of different scales (VAS,...) (vs no specific intervention)

Diuretic use vs no specific intervention

Water restriction vs no specific intervention

Outcomes:

-Reduction of relative and/or absolute risk for multiple organ failure

-NNT to prevent multiple organ failure

-Reduction of mortality related to veno-occlusive disease

-Reduction of risk of bleeding

-Pain reduction

Fresh frozen plasma (vs no specific intervention)

High dose steroid (vs no specific intervention)

Infusion of albumin (vs no specific intervention)

Transfusion of red blood cells (vs no specific intervention)

Analgesic therapy (vs no specific intervention)

Assessment of pain through the use of different scales (VAS,...) (vs no specific intervention)

Diuretic use (vs no specific intervention)

Water restriction (vs no specific intervention)

\section{Outcomes:}

-Reduction of relative and/or absolute risk for multiple organ failure

-NNT to prevent multiple organ failure

-Reduction of mortality related to veno-occlusive disease

-Reduction of risk of bleeding

-Pain reduction

Fresh frozen plasma (vs no specific intervention)

High dose steroid (vs no specific intervention)

Infusion of albumin (vs no specific intervention)

Transfusion of red blood cells with higher $\mathrm{Hb}$ target than usual (vs no specific intervention)

Analgesic therapy (vs no specific intervention)

Psychological therapy (vs no specific intervention)

Assessment of pain through the use of different scales (VAS,...) (vs no specific intervention)

Diuretic use (vs no specific intervention)

Water restriction (vs no specific intervention) 


\begin{tabular}{|c|c|}
\hline T3 In adult or pediatric patients with VOD diagnosis & $\begin{array}{l}\text { Outcomes: } \\
\text {-Reduction of relative and/or absolute risk for multiple organ failure } \\
\text {-NNT to prevent multiple organ failure } \\
\text {-Reduction of mortality related to veno-occlusive disease } \\
\text {-Reduction of risk of bleeding } \\
\text {-Reduction in supportive care needs (inotropic agents, diuretics, oxygen) } \\
\text {-Reduction of weight gain } \\
\text {-Absolute and relative risk of adverse effects and number needed to harm } \\
\text {-Normalization of ultrasound parameters } \\
\text {-Increase of platelets levels } \\
\text {-Need of therapeutic changes }\end{array}$ \\
\hline \multirow[t]{6}{*}{ Interventions } & Weight monitoring every $12 \mathrm{~h}$ vs no monitoring \\
\hline & Monitoring of fluid balance at least every $8 \mathrm{~h}$ vs no intervention \\
\hline & $\begin{array}{l}\text { Abdominal Ultrasound should be repeated during follow up. The timing for control can be } \\
\text { decided according to clinical conditions (vs no intervention) }\end{array}$ \\
\hline & Daily liver and kidney function tests (blood chemistry) (vs no intervention) \\
\hline & Signs and symptoms of bleeding \\
\hline & Signs of drug toxicity \\
\hline
\end{tabular}

Table S1: Questions (population, intervention, and outcome) voted for relevance achieving a final approved list. 


\section{Research strategy}

\begin{tabular}{|c|c|}
\hline Domains & Research strings \\
\hline Generic & $\begin{array}{l}\text { a. ("Hepatic Veno-Occlusive Disease"[Mesh]) AND "Graft vs Host Disease"[Mesh] } \\
\text { b. "Hepatic Veno-Occlusive Disease"[All Fields] AND "Graft vs Host Disease"[All Fields] AND ("2014/01/01"[PDAT]: } \\
\text { "2016/12/31"[PDAT]) } \\
\text { c. ("Bone Marrow Transplantation"[Mesh] OR "Hematopoietic Stem Cell Transplantation"[Mesh]) AND "Hepatic Veno-Occlusive } \\
\text { Disease"[Mesh] } \\
\text { d. ("Bone Marrow Transplantation"[Mesh] OR "Hematopoietic Stem Cell Transplantation"[Mesh]) AND "Veno-Occlusive Disease"[All } \\
\text { Fields] } \\
\text { e. ("Veno-Occlusive Disease" NOT (lung OR pulmonary)) AND ("Graft vs Host Disease" OR GVHD) }\end{array}$ \\
\hline $\begin{array}{c}\text { Risk assessment and } \\
\text { prevention }\end{array}$ & 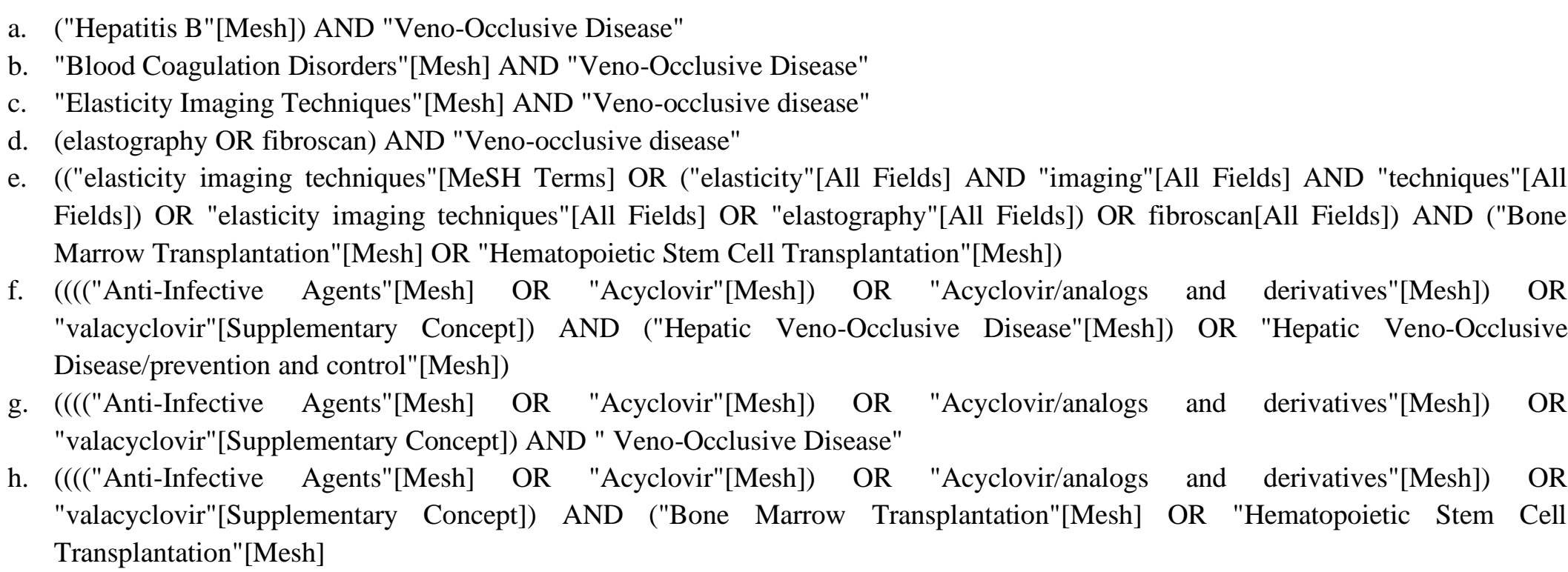 \\
\hline
\end{tabular}


i. ("Transplantation Conditioning"[Mesh]) AND "Hepatic Veno-Occlusive Disease"[Mesh]

j. ("Antineoplastic Protocols"[Mesh]) AND "Hepatic Veno-Occlusive Disease"[Mesh]

k. ("Transplantation Conditioning"[Mesh]) AND "Hepatic Veno-Occlusive Disease"[Mesh]

1. Conditioning AND "Veno-Occlusive Disease" AND (hematopoietic OR bone)

\section{Diagnosis}

a. "Hepatic Veno-Occlusive Disease/diagnosis"[Mesh]

b. ("veno-occlusive disease"[All Fields] NOT (("lung"[MeSH Terms] OR "lung"[All Fields]) OR ("lung"[MeSH Terms] OR "lung"[All Fields] OR "pulmonary"[All Fields]))) AND ("diagnosis"[Subheading] OR "diagnosis"[All Fields] OR "diagnosis"[MeSH Terms])

c. ("veno-occlusive disease"[All Fields] NOT (("lung"[MeSH Terms] OR "lung"[All Fields]) OR ("lung"[MeSH Terms] OR "lung"[All Fields] OR "pulmonary"[All Fields]))) AND (("tomography, x-ray computed"[MeSH Terms] OR ("tomography"[All Fields] AND "xray"[All Fields] AND "computed"[All Fields]) OR "x-ray computed tomography"[All Fields] OR "tomography"[All Fields] OR "tomography"[MeSH Terms]) OR ("tomography, x-ray computed"[MeSH Terms] OR ("tomography"[All Fields] AND "x-ray"[All Fields] AND "computed"[All Fields]) OR "x-ray computed tomography"[All Fields] OR ("ct"[All Fields] AND "scan"[All Fields]) OR "ct scan"[All Fields]))

d. "veno-occlusive disease"[All Fields] NOT (("lung"[MeSH Terms] OR "lung"[All Fields] OR "pulmonary"[All Fields]) OR ("lung"[MeSH Terms] OR "lung"[All Fields])) AND "Ultrasonography, Doppler"[All Fields]

e. "veno-occlusive disease"[All Fields] AND ((("veins"[MeSH Terms] OR "veins"[All Fields] OR "venous"[All Fields]) AND gradient [All Fields] AND ("pressure"[MeSH Terms] OR "pressure"[All Fields])) OR HVGP [All Fields])

f. "veno-occlusive disease"[All Fields] AND "liver biopsy"[All Fields]

g. "veno-occlusive disease"[All Fields] NOT (("lung"[MeSH Terms] OR "lung"[All Fields] OR "pulmonary"[All Fields]) OR ("lung"[MeSH Terms] OR "lung"[All Fields])) AND "biopsy"[All Fields]

h. "veno-occlusive disease"[All Fields] NOT (("lung"[MeSH Terms] OR "lung"[All Fields] OR "pulmonary"[All Fields]) OR ("lung"[MeSH Terms] OR "lung"[All Fields])) AND "MRI"[All Fields] AND ("infant"[MeSH Terms] OR "child"[MeSH Terms] OR "adolescent"[MeSH Terms])

Treatment

a. "Veno-Occlusive Disease/drug therapy"[Mesh] OR "Hepatic Veno-Occlusive Disease/therapy"[Mesh]

b. "Veno-Occlusive Disease"[All Fields] NOT (("lung"[MeSH Terms] OR "lung"[All Fields]) OR ("lung"[MeSH Terms] OR "lung"[All Fields] OR "pulmonary"[All Fields])) AND (("hematopoietic system"[MeSH Terms] OR ("hematopoietic" OR "hematopoietic"[All Fields]) OR ("bone and bones"[MeSH Terms] OR ("bone"[All Fields] AND "bones"[All Fields]) OR "bone and bones"[All Fields] 


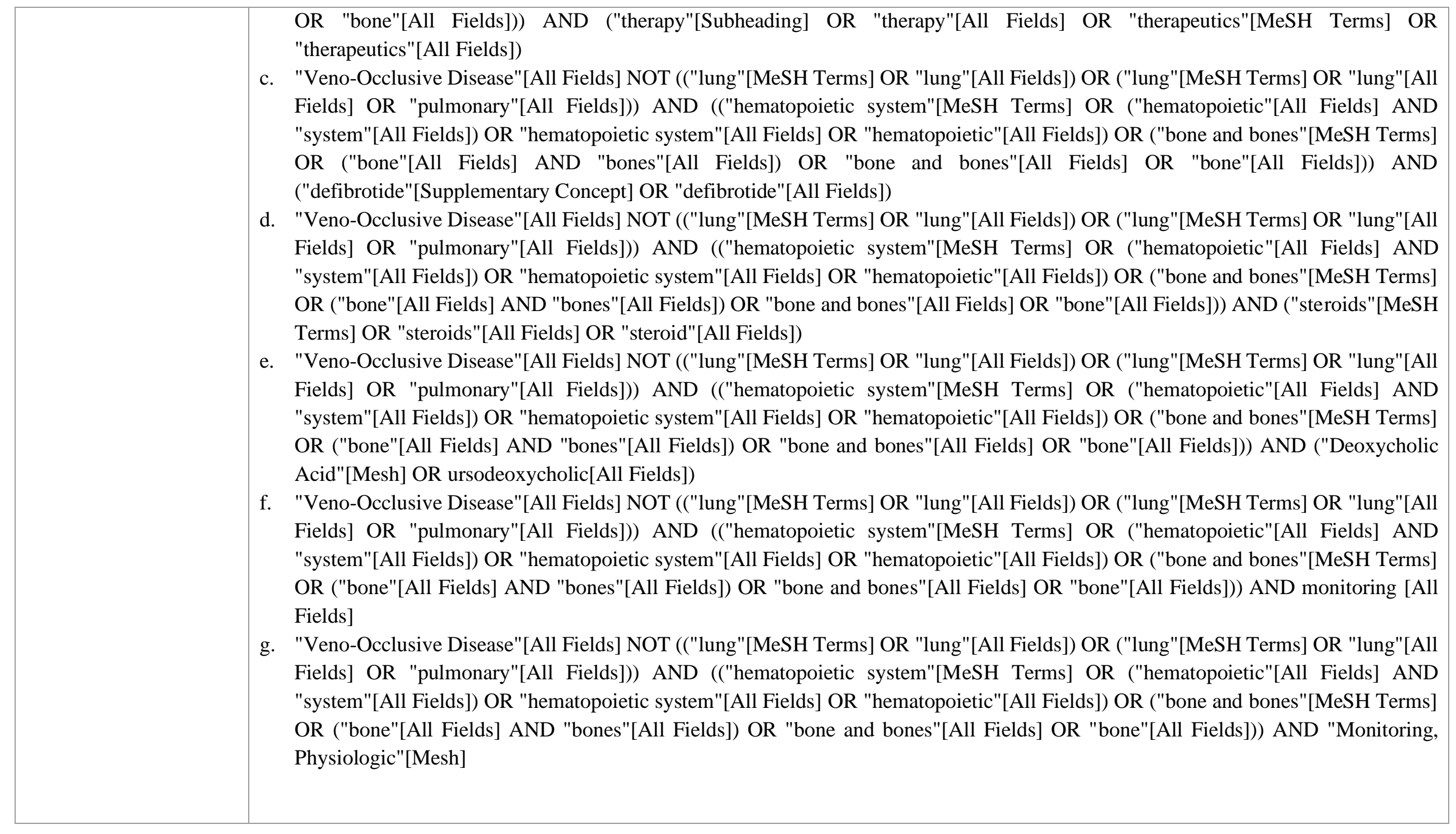

Table S2: Full research strategies. The above listed strings have been built for "PubMed" search engine., obvious adjustments in syntaxes could be needed for other search engines. 


\begin{tabular}{|c|c|c|}
\hline Title & Author & Source \\
\hline \multicolumn{3}{|c|}{ Evidence Tables: Risk/Prognosis/Prophylaxis } \\
\hline $\begin{array}{l}\text { The thiopurine methyltransferase genetic polymorphism is associated } \\
\text { with thioguanine-related veno-occlusive disease of the liver in children } \\
\text { with acute lymphoblastic leukemia }\end{array}$ & $\begin{array}{l}\text { Lennard } L \text {, et } \\
\text { al }\end{array}$ & $\begin{array}{l}\text { Clin Pharmacol Ther (2006) } \\
80(4): 375-83\end{array}$ \\
\hline $\begin{array}{l}\text { A new harmonized approach to estimate busulfan exposure predicts } \\
\text { survival and toxicity after hematopoietic cell transplantation in children } \\
\text { and young adults: a multicenter retrospective cohort study }\end{array}$ & $\begin{array}{l}\text { Bartelink IH, et } \\
\text { al }\end{array}$ & $\begin{array}{l}\text { Lancet Hematol 2016;3(11): } \\
\text { e526-e536 }\end{array}$ \\
\hline $\begin{array}{l}\text { Risk of sinusoidal obstruction syndrome in allogenic stem cell } \\
\text { transplantation after prior gentuzumab ozogamicin treatment; a } \\
\text { retrospective study from the Acute leukemia working paty of EBMT }\end{array}$ & $\begin{array}{l}\text { Battipaglia G, } \\
\text { et al }\end{array}$ & EBMT (2016) Valencia \\
\hline $\begin{array}{l}\text { High pre-transplant serum ferritin and busulfan-thiotepa conditioning } \\
\text { regimen as risk factors for hepatic sinusoidal obstructive syndrome } \\
\text { after autologous stem cell transplantation in patients with malignant } \\
\text { lymphoma }\end{array}$ & $\begin{array}{l}\text { Hwang DY, et } \\
\text { al }\end{array}$ & $\begin{array}{l}\text { Leuk Lymphoma (2016) 57(1): } \\
\text { 51-7 }\end{array}$ \\
\hline $\begin{array}{l}\text { Higher plasma bilirubin predicts veno-occlusive disease in early } \\
\text { childhood undergoing hematopoietic stem cell transplantation with } \\
\text { cyclosporine }\end{array}$ & Kim KS, et al & $\begin{array}{l}\text { World J Transplant (2016) 6(2): } \\
403-10\end{array}$ \\
\hline $\begin{array}{l}\text { Intravenous Busulfan-based myeloablative conditioning regimens prior } \\
\text { to hematopoietic cell transplantation for hematologic malignancies }\end{array}$ & $\begin{array}{l}\text { Pasquini } M C \text {, } \\
\text { et al }\end{array}$ & $\begin{array}{l}\text { Biology of Blood Marrow } \\
\text { Transplantation } 2016\end{array}$ \\
\hline $\begin{array}{l}\text { Should busulfan therapeutic range be narrowed in pediatrics? } \\
\text { Experience from a large cohort of hematopoietic stem cell transplant } \\
\text { children }\end{array}$ & $\begin{array}{l}\text { Philippe } M \text {, et } \\
\text { al }\end{array}$ & $\begin{array}{l}\text { Bone Marrow Transplant } \\
\text { (2016) 51(1): } 72-8\end{array}$ \\
\hline $\begin{array}{l}\text { Associations between levels of insulin-like growth factor } 1 \text { and } \\
\text { sinusoidal obstruction syndrome after allogeneic hematopoietic stem } \\
\text { cell transplantation }\end{array}$ & $\begin{array}{l}\text { Weischendorff } \\
\text { S, et al }\end{array}$ & $\begin{array}{l}\text { Bome } \quad \text { Marrow } \\
\text { Transplantation 2017; 1-7 }\end{array}$ \\
\hline $\begin{array}{l}\text { Sinusoidal obstruction syndrome after allogeneic hematopoietic stem } \\
\text { cell transplantation: incidence, risk factor and outcomes. }\end{array}$ & $\begin{array}{l}\text { Yakushijin K, } \\
\text { et al }\end{array}$ & $\begin{array}{l}\text { Bone Marrow Transplantation } \\
\text { 2016, 51:403-409 }\end{array}$ \\
\hline $\begin{array}{l}\text { Clinical comparison of weight- and age-based strategy of dose } \\
\text { administration in children receiving intravenous busulfan for } \\
\text { hematopoietic stem cell transplantation. }\end{array}$ & $\begin{array}{l}\text { Gökçebay D, } \\
\text { et al }\end{array}$ & $\begin{array}{l}\text { Pediatric Transplantation } \\
\text { (2015) 19: 307-315 }\end{array}$ \\
\hline $\begin{array}{l}\text { Does defibrotide prophylaxis decrease the risk of acute graft versus } \\
\text { host diseasefollowing allogeneic hematopioietic stem cell } \\
\text { transplantation? }\end{array}$ & $\begin{array}{l}\text { Tekgunduz } E \text {, } \\
\text { et al }\end{array}$ & $\begin{array}{l}\text { Transfusion and apheresis } \\
\text { science } 2016,54: 30-34\end{array}$ \\
\hline $\begin{array}{l}\text { Low, fixed dose defibrotide in management of hepatic veno-occlusive } \\
\text { disease post stem cell transplantation. }\end{array}$ & Bagal B, et al & $\begin{array}{l}\text { Hematol Oncol Stem Cell Ther } \\
\text { (2017) }\end{array}$ \\
\hline $\begin{array}{l}\text { Experience from a single pediatric transplant center with identification } \\
\text { of dome protective and risk factors concerning the development of } \\
\text { hepatic veno-occlusive disease in children after allogeneic } \\
\text { hematopoietic stem cell transplant }\end{array}$ & $\begin{array}{l}\text { Maximova N, } \\
\text { et al }\end{array}$ & $\begin{array}{l}\text { Int J Hematol 2014, 99:766- } \\
772\end{array}$ \\
\hline $\begin{array}{l}\text { Incidence and risk factors for veno-occlusive disease of the liver after } \\
\text { allogeneic stem cell transplantation using a reduced intensity regimen. }\end{array}$ & $\begin{array}{l}\text { Tsirigotis } P \text {, et } \\
\text { al }\end{array}$ & ASH (2013) New Orleans. \\
\hline $\begin{array}{l}\text { Defibrotide for prophylaxis of hepatic veno-occlusive disease in } \\
\text { paediatric haemopoietic stem-cell transplantation: an open-label, } \\
\text { phase 3, randomised controlled trial }\end{array}$ & $\begin{array}{l}\text { Corbacioglu S, } \\
\text { et al }\end{array}$ & $\begin{array}{ll}\text { Lancet } & (2012) \quad 379(9823): \\
1301-9 & \end{array}$ \\
\hline $\begin{array}{l}\text { Order of application and liver toxicity in patients given } \mathrm{BU} \text { and } \mathrm{CY} \\
\text { conditioning regimens for allogeneic hematopoietic SCT }\end{array}$ & $\begin{array}{l}\text { Cantoni } \mathrm{N} \text {, et } \\
\text { al }\end{array}$ & $\begin{array}{l}\text { Bone Marrow Transplantation } \\
\text { (2011) 46, 344-349 }\end{array}$ \\
\hline $\begin{array}{l}\text { Absence of VOD in paediatric thalassaemic HSCT recipients using } \\
\text { defibrotide prophylaxis and intravenous Busulphan }\end{array}$ & $\begin{array}{l}\text { Cappelli B, et } \\
\text { al }\end{array}$ & $\begin{array}{l}\text { Br J Haematol (2009) 147(4): } \\
554-60\end{array}$ \\
\hline $\begin{array}{l}\text { Defibrotide in the prevention and treatment of veno-occlusive disease } \\
\text { in autologous and allogeneic stem cell transplantation in children }\end{array}$ & $\begin{array}{l}\text { Qureshi } A \text {, et } \\
\text { al }\end{array}$ & $\begin{array}{l}\text { Pediatr Blood Cancer (2008) } \\
\text { 50(4): 831-2 }\end{array}$ \\
\hline $\begin{array}{l}\text { Veno-occlusive disease prophylaxis with fresh frozen plasma and } \\
\text { heparin in bone marrow transplantation }\end{array}$ & Batsis I, et al & $\begin{array}{ll}\text { Thrombosis } & \text { Research } \\
\text { 2006;118:611-618 } & \end{array}$ \\
\hline $\begin{array}{l}\text { Final Report of the efficacy and Safety of Gemtuzumab Ozogamicin } \\
\text { (Mylotarg) in patients with CD33-positive acute myeloid leukemia in } \\
\text { first recurrence }\end{array}$ & $\begin{array}{l}\text { Larson RA, et } \\
\text { al }\end{array}$ & $\begin{array}{l}\text { Cancer 2005;104(7):1442- } \\
1452\end{array}$ \\
\hline
\end{tabular}


Prognostic value of doppler-ultrasonography in hepatic veno-occlusive disease.

Multi-institutional use of defibrotide in 88 patients after stem cell transplantation with severe veno-occlusive disease and multisystem organ failure: response without significant toxicity in a high-risk population and factors predictive of outcome.

Ursodeoxycholic acid for the prevention of hepatic complications in allogeneic stem cell transplantation.

The Japanese multicenter open randomized trial of ursodeoxycholic acid prophylaxis for hepatic veno-occlusive disease after stem cell transplantation.

Parenteral glutamine protects hepatic function during bone marrow transplantation

Incidence and outcome of hepatic veno-occlusive disease after blood or marrow transplantation: a prospective cohort study of the European Group for Blood and Marrow Transplantation.

Ursodiol prophylaxis against hepatic complications of allogeneic bone marrow transplantation. A randomized, double-blind, placebocontrolled trial.

Low molecular weight heparin for the prevention of veno-occlusive disease of the liver in bone marrow transplantation patients

Iron chelation with Deferasirox prior to high-dose chemotherapy and autologous stem cell transplantation may reduce the risk of hepatic veno-occlusive disease in children with high-risk solid tumor.

Prophylactic defibrotide in allogeneic stem cell transplantation: minimal morbidity and zero mortality from veno-occlusive disease

Prophylactic fresh frozen plasma may prevent development of hepatic VOD after stem cell transplantation via ADAMTS13-mediated restoration of von Willebrand factor plasma levels.

A randomized trial of heparin plus ursodiol vs. heparin alone to prevent hepatic veno-occlusive disease after hematopoietic stem cell transplantation.
Lassau $\mathrm{N}$, et al

Richardson

$P G$, et al

Ruutu T, et al

Blood (2002) 100(6): 1977-83

Ohashi K, et al

Am J Hematol (2000) 64(1): $32-8$

Brown SA

Bone Marrow Transplantation (1998) 22: 281-2814

Carreras E, et Blood (1998) 92(10): 3599-604 al

Essell JH, et al Ann Intern Med (1998) 128(12 Pt 1): 975-81

Or $\mathrm{R}$, et al

Transplantation (1996) 61(7): 1067-71

Chueh HW, et Pediatr Blood Cancer (2012) al

58: 441-447

Dignan $F$, et al

Bone Marrow transplantation 2007:40:79-82

Matsumoto

Bone Marrow Transplant

$M$, et al (2007) 40(3): 251-9

Park SH, et al Bone Marrow Transplant (2002) 29(2): 137-43

\section{Summaries: Risk/Prognosis/Prophylaxis}

Epatic sinusoidal obstruction syndrome (SOS) following hematopoietic stem cell transplantation (HSCT): Incidence, treatment and outcome in a cohort of 1,540 patients.

Defibrotide for the prevention and treatment of hepatic veno-occlusive disease after hematopoietic stem cell transplantation; A single center experience.

Low dose unfractionated heparin (UFH) prophylaxis is a feasible strategy for the prevention of hepatic sinusoidal obstruction syndrome (SOS) after myeloablative adult allogeneic hematopoietic stem cell transplantation (HSCT)

Prophylaxis of sinusoidal obstruction syndrome after allogeneic stem cell transplantation in high-risk adult patients.

Anti-thymocyte globulin-induced hyperbilirubinemia in patients with myelofibrosis undergoing allogeneic hematopoietic cell transplantation.

Low liver fat content is a risk factor for liver related complications after allogeneic hematopoetic stem cell transplantation.

[Delayed Hepatic Veno-Occlusive Disease after Haploidentical Hematopoietic Stem Cell Transplantation:A Report of Six Cases]

Defibrotide for the prevention and treatment of hepatic veno-occlusive disease after hematopoietic stem cell transplantation; A single center experience.
Abecasis M, et EBMT (2016) Valencia al

Antmen B, et EBMT (2016) Valencia. al

Bhatt V, et al BMT (2016) Honolulu

Bonnin A, et al ESCP (2015) Lisbon

Ecsedi, et al

Ann Hematol (2016) 95:16271636

Franke GN, et EBMT (2016) Valencia, Spain al

Kang $\mathrm{HZ}$, et al

Zhongguo Shi Yan Xue Ye Xue Za Zhi (2016) 24(4): 1149-54

Antmen, BA, EBMT (2015) Istanbul. et al 
Low dose unfractionated heparin (UFH) prophylaxis is a safe strategy for the prevention of hepatic sinusoidal obstruction syndrome (SOS) in adult allogeneic stem cell transplant (HSCT) recipients.

Cyclophosphamide followed by busulphan in place of standard bucy regimen for patients undergoing allogeneic stem cell transplantation: $A$ preliminary experience from a single centre in India.

Veno occlusive disease of the liver after hematopoietic stem cell transplantation (HSCT) in pediatric patients: Padova experience.

Association of heparanase gene single nucleotide polymorphisms with veno-occlusive disease after allogeneic hematopoietic stem cell transplantation in childhood.

Recombinant thrombomodulin for the treatment of transplantationassociated coagulopathy after allogeneic hematopoietic stem cell transplantation: A multi-center study in Japan.

Association between high uric acid levels and hepatic veno-occlusive disease in HCST

Fludarabine/treosulfan/thiotepa/ATG conditioning for related transplantation in haemoglobinopathies leads to early and sustanined engraftment with low incidence of VOD and GVHD.

Low incidence of veno-occlusive disease after using intravenous busulfan in allogenic hematpoietic stem cell transplantation for acute lymphoblastic leukemia.

Evaluation of thromboelastometry parameters as predictive markers for sinusoidal obstruction syndrome in patients undergoing allogeneic stem cell transplantation for acute leukemia.

Heparanase polymorphisms: influence on incidence of hepatic sinusoidal obstruction syndrome in children undergoing allogeneic hematopoietic stem cell transplantation.

Alteration of Microparticle Levels in Early Complications During Hematopoietic Stem Cell Transplantation.

Defibrotide for the prevention and treatment of hepatic veno-occlusive disease after hematopoietic stem cell transplantation; a single center experience.

Hepatic sinusoidal obstruction syndrome in patients with malignant lymphoma undergoing autologous hematopoietic stem cell transplantation: Clinical characteristics and risk factors.

Incidence and risk factors of hepatic veno-occlusive disease after hematopoetic stem cell transplantation in children.

Experience from a single paediatric transplant centre with identification of some protective and risk factors concerning the development of hepatic veno-occlusive disease in children after allogeneic hematopoietic stem cell transplant

Hyperbilirubinemia in the early phase after allogeneic HSCT: prognostic significance of the alkaline phosphatase/total bilirubin ratio.

Coexisting or underlying risk factors of hepatic veno-occlusive disease in pediatric hematopoietic stem cell transplant recipients receiving prophylaxis

Hepatic sinusoidal obstruction syndrome after allogeneic hematopoietic stem cell transplantation in adult patients with idiopathic aplastic anemia

Prognostic and diagnostic value of endothelial damage markers for veno-occlusive disease and transplant-related mortality after allogeneic stem cell transplantation.

Safety and effects of prophylactic defibrotide for sinusoidal obstruction syndrome in hematopoietic stem cell transplantation.
Bhatt $\mathrm{V}$, et al

ASH (2015) San Diego.

Bhethanabhot

la $\mathrm{S}$, at al

BMT Tandem Meetings (2015) San Diego

Calore, et al

EBMT (2015) Istanbul.

Gruhn B, at al EBMT (2015) Istanbul.

Ishii $\mathrm{K}$, at al

ASH (2015) San Diego, CA

Karapapak M, EBMT (2015) Istanbul et al

O'Boyle F, et al ASH (2015) San Diego

Ramzi M, et al EBMT (2015) Istanbul

Rupa-Matysek ISTH (2015) Toronto

$\mathrm{J}$, et al

Seifert C, et al J Cancer Res Clin Oncol (2015) 141(5): $877-85$

Zhou LL, et al Zhongguo Shi Yan Xue Ye Xue Za Zhi (2015) 23(6): 1673-8

Antmen B, et EBMT (2014) Milan. al 40th

Jungyeon L, et 40th EBMT (2014) Milan. al

Karasu G, et al 40th EBMT (2014) Milan.

Maximova N, Int J Hematol (2014) 99(6): et al 766-72

Ashizawa M, Bone Marrow Transplant et al (2013) 48(1): 94-8

Gokce M, et al Exp Clin Transplant (2013) 11(5): 440-6

Kim H, et al Leuk Res (2013) 37(10): 12417

Moiseev l, et al EBMT (2013) London

Park $\mathrm{M}$, et al Ann Transplant (2013) 18(3642) 
Excess of veno-occlusive disease in a randomized clinical trial on a higher trigger for red blood cell transfusion after bone marrow transplantation: a canadian blood and marrow transplant group trial.

Nationwide survey of sinusoidal obstruction syndrome after allogeneic hematopoietic stem cell transplantation: Incidence, risk factors, and outcome: On behalf of complications working group of the Japan Society for Hematopoietic Cell Transplantation (JSHCT).

Less veno-occlusive disease after intravenous versus oral busulfan for autologous haematopoietic stem cell transplantation: The Belgian paediatric experience.

Possible correlation of sirolimus plasma concentration with sinusoidal obstructive syndrome of the liver in patients undergoing myeloablative allogeneic hematopoietic cell transplantation.

Association of iron overload with survival and complications in allogeneic hematopoietic cell transplant recipients: Prospective cohort study using R2-MRI measured liver iron content.

Measurement of liver iron concentration by quantum interference device biosusceptometry (SQUID) validates serum ferritin as prognostic parameter for allogeneic stem cell transplantation

Veno-occlusive disease in pediatric patients after hematopoietic stem cell transplantation: relevance of activated coagulation and fibrinolysis markers and natural anticoagulants.

Retrospective analysis of effectiveness of veno-occlusive prophylaxis guidelines implemented for patients receiving hematopoietic stem cell transplantation

Recombinant thrombomodulin may play a preventive role for venoocclusive disease after hematopoietic stem cell transplantation

Successful treatment with low-dose gemtuzumab ozogamicincombined chemotherapy followed by unrelated stem cell transplantation for children with refractory acute myeloid leukaemia.

Defibrotide low-dose continuous infusion after allogeneic stem cell transplantation as prophylaxis for veno-occlusive disease of the liver.

Prior treatment with gemtuzumab ozogamicin and the risk of venoocclusive disease after allogeneic haematopoietic stem cell transplantation.

Liver fibrosis and the risk of hepatic veno-occlusive disease in children with beta thalassemia disease undergoing allogeneic haematopoietic stem-cell transplantation.

A linked donor recipient study to evaluate $B$ and $C$ hepatitis virus transmission and liver dysfunction after allogeneic bone marrow transplantation.

Veno-occlusive disease after haematopoietic stem cell transplantation for $\beta$ thalassaemia major is predicted by the severity of hepatic fibrosis and ameliorated by defibrotide.

Comparison of outcomes after allogeneic SCT for adult patients with $A M L$ in remission using either I.V. Busulfan plus cyclophosphamide or TBI plus CY in the myeloablative conditioning regimen: An- ALWP-EBMT survey

A prospective study on incidence, etiology, risk factors and outcomes of hepatic dysfunction after hematopoietic stem cell transplantation.

Hepatitis $C$ and $B$ virus infection and liver dysfunction after allogeneic bone marrow transplantation: Results from a retrospective study.

Incidence of veno-occlusive disease with IV in Busulfan children is higher than expected: Preliminary results of the VOD-DF trial.
Robitaille $\mathrm{N}$, et al

Biol Blood Marrow Transplant 19 (2013) 468-473.

Yakushijin K, ASH (2013) New Orleans. et al

Huybrechts SJ, 38th EBMT (2012) Geneva et al

Kiel PJ, et al

Pharmacotherapy 32(5): 441-5

Trottier BJ, et ASH (2012) Atlanta. al

Jacobi N, et al ASH (2011) San Diego

Jevtic D, et al J Pediatr Hematol Oncol (2011) 33(3): 227-34

$\mathrm{Ng} \mathrm{HY}$, et al

BMT Tandem Meetings (2011) Honolulu

Nomura $S$, et Journal of Thrombosis and al Haemostasis (2011) 9(SUPPL. 2): 177

Yoshida N, et EBMT (2011) Paris, France al

Bonini A, et al ASH 2010 Orlando

Chevallier $\mathrm{P}$, et Service d'Hematologie

al Clinique, CHU Hotel-Dieu, Nantes, Cedex 01, France

Chongsrisawat EASL, International Liver V, et al Congress (2010) Vienna

Console G, et EBMT (2010) Vienna. al

Hiwarkar P, et ASH (2010) Orlando, FL, al United States

Nagler A, et al EBMT (2010) Vienna, Austria

Rastogi SK

ISGCON (2010) Hyderabad, India.

Console $\mathrm{G}$, et 42 Congress of the Italian al Society of Hematology (2009) Milano, Italy

Corbacioglu S, ASH (2009) New Orleans, LA, et al United States 
Efficacy of ursodeoxycholic acid with low-dose heparin and prostaglandin E1 in the prevention of hepatic veno-occlusive disease after allogenic hematopoietic stem cell transplantation in children with $\beta$-thalassemia major

[The effect of hepatitis $B$ virus infection on the outcome of hematopoietic stem cell transplantation]

Low dose heparin for the prevention of hepatic veno-occlusive disease after allogeneic hematopoietic stem cell transplantation]

Stem cell transplantation in children with infantile osteopetrosis is associated with a high incidence of VOD, which could be prevented with defibrotide.

Time-related changes in the incidence, severity, and clinical outcome of hepatic veno-occlusive disease in hematopoietic stem cell transplantation patients during the past 10 years

Decreased incidence of hepatic veno-occlusive disease and fewer hemostatic derangements associated with intravenous busulfan vs oral busulfan in adults conditioned with busulfan + cyclophosphamide for allogeneic bone marrow transplantation.

Liver disease is a major cause of mortality following allogeneic bonemarrow transplantation.

Low molecular weight heparin for the prevention of hepatic venoocclusive disease (VOD) after hematopoietic stem cell transplantation: a prospective phase II study.

Cyclophosphamide metabolism, liver toxicity, and mortality following hematopoietic stem cell transplantation.

Retrospective study on the impact of hepatitis B and hepatitis C virus infection on hematopoietic stem cell transplantation in Japan.

Retrospective multivariate analysis of hepatic veno-occlusive disease after blood or marrow transplantation: possible beneficial use of low molecular weight heparin.

The impact of hepatitis B virus infected patients or donors on the outcome of hematopoietic stem cell transplantation.

The role of hepatitis $C$ and $B$ virus infections as risk factors for severe liver complications following allogeneic BMT: a prospective study by the Infectious Disease Working Party of the European Blood and Marrow Transplantation Group.

Low incidence of hepatic veno occlusive disease (VOD) using ursodeoxyholic acid (Ursodiol) and heparin prophylaxis in pediatric hematopoietic progenitor cell transplant (HPCT) patients at the medical college of wisconsin.

Clinical impact of hepatitis $b$ surface antigen positivity in patients undergone allogeneic hematopoietic stem cell transplantation

Effectiveness of ursodeoxycholic acid as prophylactic agent against hepatic sinusoidal obstruction syndrome in patients undergoing allogeneic hematopoietic cell transplantation for treatment of hematological malignancies. $\mathrm{Ng}$,

Intravenous versus oral busulfan administration results into a dramatic reduction of veno-occlusive disease (VOD) incidence in a randomised trial assessing fresh frozen plasmatheparin versus heparin-alone as anti-VOD prophylaxis.

Transient elastography (FibroScan) for the prediction of liver toxicity following autologous or allogeneic HSCT.

Analysis of the incidence and characteristics of venoocclusive disease (VOD) of the liver in pediatric Hematopoietic Progenitor Cell Transplant
Wu X, et al

ASH (2009) New Orleans, LA

Du H, et al

Zhonghua Liu Xing Bing Xue Za Zhi (2008) 29(4): 387-91

Chen J, et al Zhonghua Nei Ke Za Zhi (2007) 46(2): 140-2

Corbacioglu S, Bone Marrow Transplant et al (2006) 38(8): 547-53

Kalayoglu-

Besisik S

Transplant Proc (2005) 37(5): 2285-9

Lee $\mathrm{JH}$, et al

Ann Hematol (2005) 84(5): 321-30

El-Sayed $\mathrm{MH}$, et al

Eur J Gastroenterol Hepatol (2004) 16(12): 1347-54

Forrest DL, et Bone Marrow Transplant al (2003) 31(12): 1143-9

McDonald GB, Blood (2003) 101(5): 2043-8 et al

Hamaguchi M, International Journal of et al Hematology (2002) 75(3): 324331

Simon M, et al Bone Marrow Transplant (2001) 27(6): 627-33

Feng S, et al

Zhonghua Xue Ye Xue Za Zhi (2000) 21(8): 414-6

Locasciulli A, Transplantation (1999) 68(10): et al 1486-91

Vinitsky A, at ASPHO (2015) Phoenix al

Yi H, et al

20th Congress of the European Hematology Association Vienna

$\mathrm{Ng} \mathrm{HY}$, et al ASH (2012) Atlanta

Yannaki E, et al

EBMT (2012) Geneva.

Nachbaur D

Onkologie (2011)

Brown J, et al ASPHO (2010) Montreal 
(HPCT) patients with heparin alone vs. heparin and ursodiol prophylaxis at the Medical College of Wisconsin.

High exposures to bioactivated cyclophosphamide are related to the occurrence of veno-occlusive disease of the liver following high-dose chemotherapy

Gemtuzumab, fludarabine, cytarabine, and cyclosporine in patients with newly diagnosed acute myelogenous leukemia or high-risk myelodysplastic syndromes.

Gemtuzumab ozogamicin, fludarabine, cytarabine and cyclosporine combination regimen in patients with $\mathrm{CD} 33+$ primary resistant or relapsed acute myeloid leukemia

Conditioning therapy with intravenous busulfan and cyclophosphamide (IV BuCy2) for hematologic malignancies prior to allogeneic stem cell transplantation: a phase II study.

Ursodiol does not prevent hepatic venoocclusive disease associated with Mylotarg therapy.

6-thioguanine-induced hepatic veno-occlusive disease (VOD): Three case reports and their risk management.

Busulphan-melphalan is the superior myeloablative therapy (MAT) for high risk neuroblastoma: Results from the HR-NBL1/siopen trial.

Gemtuzumab ozogamicin-induced sinusoidal obstructive syndrome treated with defibrotide: a case report. de Jonge ME, .Br J Cancer (2006) 94(9):

et al 1226-30

Tsimberidou Cancer (2003) 97(6): 1481-7

A, et al

Tsimberidou

Leuk Res (2003) 27(10): 893-7

A, et al

Andersson BS, Blood Marrow Transplant

et al (2002) 8(3): 145-54

Giles F, et al

Haematologica (2002) 87(10): 1114-6

Jantzem $\mathrm{H}$, et Fundamental and Clinical al Pharmacology 27: 65, Jun 2013.

Ladenstein R, SIOP (2011) Auckland. et al

Lannoy D, et al J Clin Pharm Ther (2006) 31(4): 389-92

\section{Evidence Tables: Diagnosis}

Usefullness of liver stiffness measurement in predicting hepatic venoocclusive disease development in patients who undergo HSCT.

Sonographic appearance of the gallbladder in the allogeneic hematopietic stem cell transplant population

Anicteric veno-occlusive disease after hematopoietic stem cell transplantation in children

The diagnostic value of hepatic arterial velocity in venoocclusive disease after pediatric hematopoietic stem cell transplantation.

Veno-occlusive disease of the liver in the absence of elevation in bilirubin in pediatric patients after hematopoietic stem cell transplantation

Safety and utility of transjugular liver biopsy in hematopoietic stem cell transplant recipients

Terminal hepatic venule injury in liver biopses of allogeneic haematopoietic stem cell recipients - a study of 63 cases.

\section{Summaries: Diagnosis}

MRI patterns in a case of 6-Thioguanine related hepatic SOS

Diagnosis of SOS by PET/TAC: report of two cases treated by defibrotide

A novel protocol decreased incidence of hepatic VOD and improved results in hematopoietic cell transplantations for patients with $\beta$ talassemia major.

Platelet consumption and platelet transfusion refractoriness is a reliable early marker of veno-occlusive liver disease in a subgroup of paediatric haematopoietic stem cell transplant recipients.

CT imaging of hepatic veno-occlusive disease (an analysis 14 cases).

MR imaging findings in a patient with hepatic veno-occlusive disease
Colecchia A, et al

Bone Marrow Transplantation (2016) 1-4

Sarma A, et al J Ultrasound Med 2016;35: e35-e41.

Naples JC, et al Bone Marrow Transplantation 2016, 51:135-137

Kaya MD, et al J Pediatric Hematol Oncol (2017) 39: 249-253

Myers KC, et al Bio Blood Marrow Transplant 2015; 21(2):379-381

Kis B, et al J Vasc Interv Radiol 2013, 24:85-89 Histopathology (2016) 68: 996-1003

\begin{tabular}{|c|c|c|}
\hline $\begin{array}{l}\text { Marasco G, et } \\
\text { al }\end{array}$ & $\begin{array}{l}\text { Am } \quad \text { J } \\
2016 ; 111: 767\end{array}$ & Gastroenter \\
\hline authè $M$, et & $\begin{array}{l}\text { Hepatology } \\
1791\end{array}$ & 201 \\
\hline
\end{tabular}

Li C, et al ASH (2014) San Francisco

Svec $P$, et al

40th EBMT (2014) Milan

Zhang GH, et al Chinese Journal of Radiology (2006) 40(3): 250-254

Dumont C, et Acta Gastroenterol Belg (2004) al 67(2): $236-8$ 
Veno-occlusive disease/sinusoidal obstruction syndrome: Diagnostic patterns among united states and european union hematologists and oncologists managing patients receiving stem cell transplantation.

Incidence of hepatic veno-occlusive disease (VOD) in premier research database.

Terminal hepatic venule injury in liver biopsies of allogeneic haematopoietic stem cell recipients-a study of 63 cases.

The effectiveness of noninvasive transabdominal ultrasound evaluation in the early diagnosis of hepatic veno-occlusive disease after hematopoietic stem cell transplantation.

Biomarkers for Diagnosis and Prognosis of Sinusoidal Obstruction Syndrome after Hematopoietic Cell Transplantation.

Microparticles, plasminogen activator inhibitor (PAI-1), and antithrombin: Key players of veno-occlusive disease.

Diagnosis of sinusoidal obstruction syndrome/veno-occlusive disease of the liver: Problems of interpretation

Prognostic and diagnostic value of endothelial damage markers for veno-occlusive disease and transplant-related mortality after allogeneic stem cell transplantation.

Nationwide survey of sinusoidal obstruction syndrome after allogeneic hematopoietic stem cell transplantation: Incidence, risk factors, and outcome: On behalf of complications working group of the Japan Society for Hematopoietic Cell Transplantation (JSHCT).

Evaluation of transjugular liver biopsy in the diagnosis of early hepatic dysfunction after allogeneic haematopoietic cell transplantation.

$\mathrm{N}$-terminal pro-brain natriuretic peptide role in early diagnosis of hepatic veno-occlusive disease and severe sepsis following allogeneic haematopoietic stem cell transplantation-a single-centre experience.

Clinicopathologic features of late-onset veno-occlusive disease/sinusoidal obstruction syndrome after high dose intravenous busulfan and hematopoietic cell transplant

Ultrasonography evaluation with study of vascular hepatic flows before transplantation is useful in liver failure occurring after haemopoietic stem cell transplantion.

Severe hepatocellular injury after haematopoietic cell transplant: incidence, etiology and outcome.

CT features of hepatic venoocclusive disease and hepatic graft-versushost disease in patients after hematopoietic stem cell transplantation. Demonstration of reversed flow in segmental branches of the portal vein with hand-held color Doppler ultrasonography after hematopoietic stem cell transplantation.

Hepatic veno-occlusive disease in children undergoing bone-marrow transplantation: usefulness of sonographic findings

Hepatic veno-occlusive disease after myeloablative treatment and bone marrow transplantation: value of gray-scale and Doppler US in 100 patients.

Acoustic radiation force impulse elastography and contrast-enhanced sonography of sinusoidal obstructive syndrome (Veno-occlusive Disease): preliminary results.
Corn T, et al

BMT (2016) Honolulu.

Dvorak, et al

BMT (2016) Honolulu.

Ma C, et al

Nishida $M$, et al

Akil $\mathrm{A}$, et al

Histopathology (2016) 68(7): 996-1003

Digestive Disease Week 2016, DDW 2016 San Diego,

Biology of Blood and Marrow Transplantation (2015) 21(10): 1739-1745

Piccin A, et al

Journal of Extracellular Vesicles (2015) 4(SUPPL. 1): 152-153

Volin L, et al

Blood (2015) 126(23): 1918

Moiseev l, et al EBMT (2013) London

Yakushijin K, ASH (2013) New Orleans et al

Castillo N, et al 38th EBMT (2012) Geneva

Ciocarlie O, et Bone Marrow Transplantation al (2012) 47(SUPPL. 1): S189S190

Pal R, et al Leuk Lymphoma (2012) 53(8): 1552-7

Parma M, et al EBMT (2010) Vienna, Austria

Sakai M, et al

BMT (2009) 44(7) 441-447

Erturk SM, et AJR Am J Roentgenol (2006) al 186(6): 1497-501

Hashiguchi M, Bone Marrow Transplant et al (2005) 36(12): 1071-5

$\begin{array}{ll}\text { McCarville } & \text { Pediatr Radiol (2001) 31(2): } \\ \text { MB, et al } & 102-5 \\ \text { Lassau N, et al } & \text { Radiology (1997) 204(2): 545- } \\ & 52\end{array}$

Fontanilla T, et J Ultrasound Med (2011) al 30(11): $1593-8$

\section{Evidence Tables: Treatment/Cost}

Defibrotide for Patients with Hepatic Veno-Occlusive Richardson PG Biol Blood Marrow Transplant. Disease/Sinusoidal Obstruction Syndrome: Interim Results from a Treatment IND Study.

Burden of illness associated with sinusoidal osbstruction Cao Z, et al 2017 Jun;23(6): 997-1004 Epub 2017 Mar 8 syndrome/veno-occlusive disease in patients with hematopoietic stem cell transplantation J Med Econom 2017 (accettato per la pubblicazione 31 maggio) 
Burden impact and cost-effectiveness of defibrotide for treatment of veno-occlusive disease with multi-organ dysfunction in patients posthematopoietic stem cell transplant

Defibrotide for the Treatment of Hepatic Veno-Occlusive Disease: Final Results From the International Compassionate-Use Program

Phase 3 trial of defibrotide for the treatment of severe veno-occlusive disease and multi-organ failure.

Defibrotide for Treatment of Severe Veno-Occlusive Disease in Pediatrics and Adults: An Exploratory Analysis Using Data from the Center for International Blood and Marrow Transplant Research.

Escalation to High Dose Defibrotide in Patients with Hepatic VenoOcclusive Disease

Low, fixed dose defibrotide in management of hepatic veno-occlusive disease post stem cell transplantation.

Experience of t-PA use in moderate to severe hepatic venoocclusive disease after hematopoietic SCT: is it still reasonable to use t-PA?

Defibrotide for Treatment of Severe Veno-Occlusive Disease and Multiorgan Failure after stem cell transplantation: a multicenter, randomized, dose-finding trial.

Defibrotide in the prevention and treatment of veno-occlusive disease in autologous and allogeneic stem cell transplantation in children

Multi-institutional use of defibrotide in 88 patients after stem cell transplantation with severe veno-occlusive disease and multisystem organ failure: response without significant toxicity in a high-risk population and factors predictive of outcome.

Defibrotide for the treatment of hepatic veno-occlusive disease: results of the European compassionate-use study.

Stem cell transplantation in children with infantile osteopetrosis is associated with a high incidence of VOD, which could be prevented with defibrotide.

Results of Inotuzumab Ozogamicin, a CD22 Monoclonal Antibody, in Refractory and Relapsed Acute Lymphocytic Leukemia.

Hepatic adverse event profile of inotuzumab ozogamicin in adult patients with relapsed or refractory acute lymphoblastic leukaemia: results from the open-label, randomised, phase 3 INO-VATE study.

Salvage Chemoimmunotherapy With Inotuzumab Ozogamicin Combined With Mini-Hyper-CVD for Patients With Relapsed or Refractory Philadelphia Chromosome-Negative Acute Lymphoblastic Leukemia: A Phase 2 Clinical Trial.

\section{Summaries: Treament/Cost}

Updated results from a large, ongoing, treatment IND study using defibrotide for patients with hepatic veno-occlusive disease.

Interventional therapy of hepatic veno-occlusive disease: An analysis of 21 cases

TIPS for veno-occlusive disease following stem cell transplantation

Recombinant Human tissue plasminogen activator without heparin is effective in the treatment of hepatic veno-occlusive disease

Heterogeneous response to recombinant thrombomodulin by grade of SOS after pediatric SCT

Veno-occlusive disease in children on chemotherapy outside bone marrow transplant setting responds to defibrotide.
Veenstra DL, J Med Econom 2017

et al

Corbacioglu S, Biology of Blood and Marrow et al Transplantation (2016) 22(10): 1874-1882

Richardson Blood (2016) 127(13): 1656-

PG, et al 1665

Strouse C, et al

Biology of blood and Marrow transplantation (2016)

Brandon $\mathrm{M}$, et al

Biol Blood Marrow Transplant. 2015 Dec; 21(12): 2148-2153

Bagal B, et al Hematol Oncol Stem Cell Ther (2017)

Yoon JH, et al

Bone Marrow Transplantation 2013;48:1562-1568

Richardson Biology of blood and Marrow PG, et al transplantation 2010, 16(7):1005-1017

Qureshi A, et al Pediatr Blood Cancer (2008)

Richardson 50(4): 831-2 $P G$, et al

Blood (2002) 100(13): 4337-43

Chopra R, et al

British Journal of Haematology (2000) 111: 1122-1129.

Corbacioglu S, Bone marrow transplantation et al (2006) 38(1): 547-553

Hagop M Cancer. August 1, 2013 Kantarjian, et al
Hagop
M Lancet Haematology. Kantarjian et July 4, 2017.

al.

Elias Jabbour JAMA Oncol. 2017 Aug 31 MD et al 
Incidence and management of hepatic severe veno-occlusive disease in 273 patients in a single center with defibrotide.

Nationwide survey of defbrotide and recombinant human soluble thrombomodulin for treatment of sinusoidal obstruction syndrome after allogeneic hematopoietic stem cell transplantation.

Use of defibrotide to treat transplant-associated thrombotic microangiopathy-a retrospective study of the paediatric diseases and inborn errors working parties of EBMT.

Altered defibrotide treatment regimen for veno-occlusive disease: A single center experience.

Defibrotide for the prevention and treatment of hepatic veno-occlusive disease after hematopoietic stem cell transplantation; A single center experience.

Recombinant thrombomodulin for the treatment of transplantationassociated coagulopathy after allogeneic hematopoietic stem cell transplantation: A multi-center study in Japan.

Defibrotide for the treatment of hepatic veno-occlusive disease/sinusoidal obstruction syndrome following hematopoietic stem cell transplantation or chemotherapy-results from the Italian therapeutic use protocol.

Safety of peritoneal and pleural drain placement in pediatric stem cell transplant recipients with severe veno-occlusive disease

Defibrotide in the treatment of hepatic veno-oclusive disease after allogeneic stem cell transplantation: A retrospective single center experience

A single centre experience in Veno-occlusive disease and defibrotide Favorable outcome of veno-occlusive disease with preemptive and aggressive supportive care approach following myeloablative allogeneic hematopoietic stem cell transplantation in children+C1502:C1503.

Defibrotide in veno-occlusive disease in public hospitals of Paris: Funding issues and perspectives.

Defibrotide for the prevention and treatment of hepatic veno-occlusive disease after hematopoietic stem cell transplantation; a single center experience.

Defibrotide for sinusoidal obstruction syndrome: A single centre experience.

High-dose methylprednisolone for veno-occlusive disease of the liver in pediatric hematopoietic stem cell transplantation recipients.

Concentrated ascites reinfusion therapy for sinusoidal obstructive syndrome after hematopoietic stem cell transplantation

Treatment of hepatic venoocclusive disease with protein $\mathrm{C}$ concentrate-a single institution experience

An untimely reminder of an uncommon complication: Severe venoocclusive disease with extensive hepatocyte necrosis following autologous stem cell transplantation for relapsed Hodgkin's lymphomacase report and review of the literature

Recombinant human soluble thrombomodulin for the treatment of hepatic sinusoidal obstructive syndrome post-allogeneic hematopoietic SCT

Successful treatment with recombinant soluble thrombomodulin of two cases of sinusoidal obstructive syndrome/hepatic veno-occlusive disease after bone marrow transplantation
Pol RR, et al

Bone Marrow transplantation 2016.

Yakushijin K, EBMT (2016) Valencia.

et al

Yeates L, et al

EBMT (2016) Valencia, Spain

Zuckerman T, EBMT (2016) Valencia, Spain et al

Antmen BA, et EBMT (2015) Istanbul.

al

Ishii K, et al

ASH (2015) San Diego, CA

Locatelli, et al ASH (2015) San Diego

Madenci AL, et EBMT (2015) Istanbul al

Patir P, et al EBMT (2015) Istanbul

Pol R, et al EBMT (2015) Istanbul

Rayner P, et al ASPHO (2015) Phoenix.

Steelandt J, et 18th ISPOR (2015) Milan

al

Antmen B, et 40th EBMT (2014) Milan. al

Ruiz Ramos J, 19th EAHP (2014) Barcelona. et al

Myers KC, et al Biol Blood Marrow Transplant (2013) 19(3): 500-3

Tayfun F, et al Pediatric Blood and Cancer (2013) 60(SUPPL. 3): 243

Gruhn B, et al Jahrestagung der Gesellschaft fur Thrombose- und Hamostase - Forschung e. V., GTH St. Gallen, Switzerland 2012-02-01 to 2012-02-04

Lang KJ, et al British Journal of Haematology (2012) 157(SUPPL. 1): 46

Nakamura D, Bone Marrow Transplantation et al 2012;47,463-464

Ohwada C, et Am J Hematol (2011) 86(10): al 886-8 
Use of CRRT-CVVH in a hemato-oncological ICU in patients treated with defibrotide for veno-occlusive disease in patients after allogeneic hematopoetic stem cell transplantation: Single-center experience.

Use of low molecular weight heparin for treatment of veno-occlusive disease in pediatric bone marrow transplant patients.

Veno-occlusive disease (VOD) of the liver in Korean patients following allogeneic bone marrow transplantation (BMT): efficacy of recombinant human tissue plasminogen activator ( $\mathrm{rt}-\mathrm{PA}$ ) treatment.

Pooled dose response analysis of defibrotide in $\geq 1600$ patients for the treatment of hepatic veno-occlusive disease/sinusoidal obstruction syndrome.

Hepatic veno-occlusive disease after tandem autologous stem cell transplantation conditioned by melphalan

Liver transplantation for sinusoidal obstructive syndrome (venoocclusive disease): case report with review of the literature and the UNOS database.

Late occurrence of hepatic veno-occlusive disease following gemtuzumab ozogamicin: successful treatment with defibrotide.

Glutamine and vitamin $E$ in the treatment of hepatic veno-occlusive disease following high-dose chemotherapy

Transjugular intrahepatic portosystemic shunting (TIPS) for treatment of severe hepatic veno-occlusive disease.

A Phase II Study of Weekly Inotuzumab Ozogamicin (InO) in Adult Patients with CD22-Positive Acute Lymphoblastic Leukemia (ALL) in Second or Later Salvage.

Frontline Inotuzumab Ozogamicin in Combination with Low-Intensity Chemotherapy (mini-hyper-CVD) for Older Patients with Acute Lymphoblastic Leukemia (ALL)

Phase 1 study of inotuzumab ozogamicin combined with r-gdp for the treatment of patients with relapsed/refractory $\mathrm{cd} 22+$ b-cell nonhodgkin lymphoma.

Randomized, phase 3 trial of inotuzumab ozogamicin plus rituximab versus chemotherapy plus rituximab for relapsed/refractory aggressive B-cell non-Hodgkin lymphoma

Salvage Chemotherapy with Inotuzumab Ozogamicin (INO) Combined with Mini-Hyper-CVD for Adult Patients with Relapsed/Refractory (R/R) Acute Lymphoblastic Leukemia (ALL).

Sistematic Review

Interventions for prophylaxis of hepatic veno-occlusive disease in people undergoing haematopoietic stem cell transplantation.

Defibrotide for the prevention of hepatic veno-occlusive disease after hematopoietic stem cell transplantation: a systematic review.

Systematic review of controlled clinical trials on the use of ursodeoxycholic acid for the prevention of hepatic veno-occlusive disease in hematopoietic stem cell transplantation.

Gemtuzumab ozogamicin for treatment of newly diagnosed acute myeloid leukaemia: a systematic review and meta-analysis.

Hepatic veno-occlusive disease following stem cell transplantation: incidence, clinical course, and outcome.
Navratil $M$, et al

ISICEM

Belgium

Hipps J, et al

American Society of Pediatric Hematology/Oncology 22nd Annual Meeting (2009) San Diego.

Lee $\mathrm{JH}$, et al

J Korean Med Sci (1996) 11(2): 118-26

Martin PL, et al

2016 BMT Tandem Meetings Honolulu, HI, United States 2016-02-18 to 2016-02-22

Labidi SI, et al Int J Hematol (2008) 88(3): 291-3

Membreno FE, Clin Transplant (2008) 22(4): et al 397-404

Saviola A, et al Br J Haematol (2003) 123(4): 752-3

Goringe AP, et Bone Marrow Transplant al (1998) 21(8): 829-32

Smith FO, et al Bone Marrow Transplant (1996) 18(3): 643-6

Advani AS Blood 2014

Jabbour E, et Blood 2015 al

Sangha R, et al J Drug Assess.

Aug. 2017

Dang NH, et al Br. J Haematol. 2017

Sasaky, et al Blood 2015

Cheuk DK, et al Cochrane Database Syst Rev (2015) 5): CD009311

Zhang L, et al Clin Transplant 2012

Tay J, et al

Biol Blood Marrow Transplant (2007) 13(2): 206-17

Kharfan- $\quad$ Br J Haematol (2013) 163(3):

Dabaja MA, et 315-25

al

Coppell JA, et Biol Blood Marrow Transplant al (2010) 16(2): 157-68

\section{Evidence Based-guideline}

BCSH/BSBMT guideline: diagnosis and management of veno-occlusive disease (sinusoidal obstruction syndrome) following haematopoietic Dignan $\mathrm{FL}$, et al Br J Haematol (2013) 163(4): 444-57

stem cell transplantation 


\begin{tabular}{|c|c|c|}
\hline $\begin{array}{l}\text { Inotuzumab ozogamicin in relapsed B-cell acute lymphoblastic } \\
\text { leukemia }\end{array}$ & & $\begin{array}{l}\text { Eur J Haematol. 2017;98:425- } \\
434\end{array}$ \\
\hline $\begin{array}{l}\text { Inotuzumab ozogamicin for the treatment of acute lympho } \\
\text { leukemia }\end{array}$ & & $\begin{array}{l}\text { Expert Opinion on Biological } \\
\text { Therapy, } 2017\end{array}$ \\
\hline $\begin{array}{l}\text { Treatment of adult acute lymphoblastic leukemia with inotu } \\
\text { ozogamicin }\end{array}$ & & ne, 2017 \\
\hline $\begin{array}{l}\text { Revised diagnosis and severity criteria for sinusoidal obstruction } \\
\text { syndrome/veno-occlusive disease in adult patients: a new classification } \\
\text { from the European Society for Blood and Marrow Transplantation }\end{array}$ & & $\begin{array}{l}\text { Bone Marrow Transplantation } \\
\text { (2016) 51, 906-912; }\end{array}$ \\
\hline $\begin{array}{l}\text { Diagnosis and severity criteria for sinusoidal obstruction } \\
\text { syndrome/veno-occlusive disease in pediatric patients: a new } \\
\text { classification from the European society for blood and marrow } \\
\text { transplantation }\end{array}$ & $\begin{array}{l}\text { Corbacioglu S, } \\
\text { et al }\end{array}$ & $\begin{array}{l}\text { Bone Marrow Transplantation } \\
\text { volume 53, pages138- } \\
\text { 145(2018) }\end{array}$ \\
\hline
\end{tabular}

Table S3: Relevant paper included in the Evidence Report 


\begin{tabular}{|c|c|c|c|}
\hline \multicolumn{4}{|c|}{ RISK / PROPHYLAXIS } \\
\hline & Notes & Median (IQR) & $\begin{array}{c}\text { Strong } \\
\text { agreement (\%) }\end{array}$ \\
\hline \multicolumn{4}{|l|}{ Grade of Recommendation: STRONG } \\
\hline $\begin{array}{l}\text { R1 Risk factors for VOD must be assessed and registered in clinical } \\
\text { records for all candidates undergoing SCT. }\end{array}$ & & $9(8-9)$ & $94.44 \%$ \\
\hline $\begin{array}{l}\text { R2 Pediatric patients undergoing SCT for thalassemia major (Pesaro } \\
\text { class } \geq 2 \text { or hepatic fibrosis } \geq \text { stage } 3 \text { ), malignant infantile } \\
\text { osteopetrosis are at increased risk of VOD. }\end{array}$ & & $8(8-9)$ & $83.33 \%$ \\
\hline $\begin{array}{l}\text { R3 All patients undergoing SCT previously treated with gentuzumab, } \\
\text { inotuzumab or conditioned with myeloablative TBI, busulfan are at } \\
\text { increased risk of VOD. }\end{array}$ & $\begin{array}{l}\text { SCTs performed (within } 30 \text { days from) after } \\
\text { inotuzumab or gentuzumab treatment are at } \\
\text { particularly high risk of VOD. }\end{array}$ & $8(8-9)$ & $83.33 \%$ \\
\hline $\begin{array}{l}\text { R4 In all patients undergoing SCT the use of oral busulfan instead of } \\
\text { intravenous busulfan, exposure to sovra-optimal busulfan levels or if } \\
\text { conditioned with }>2 \text { alkylating agents increases the risk of VOD. }\end{array}$ & & $8(7-8)$ & $66.67 \%$ \\
\hline $\begin{array}{l}\text { R10 In all patients undergoing SCT at risk of VOD, prophylaxis with } \\
\text { UDCA } 12-15 \mathrm{mg} / \mathrm{kg} / \text { die starting before-transplant till day }+100 \text { post- } \\
\text { SCT is recommended in order to reduce VOD risk. }\end{array}$ & $\begin{array}{l}\text { The panel believes that prophylaxis with UDCA is } \\
\text { effective in the presence of any risk factor. }\end{array}$ & $8(8-9)$ & $83.33 \%$ \\
\hline $\begin{array}{l}\text { R11 In all patients undergoing SCT, busulfan administered } \\
\text { intravenously is recommended in order to reduce the risk of VOD. }\end{array}$ & Instead of orally. & $8(8-9)$ & $88.89 \%$ \\
\hline \multicolumn{4}{|l|}{ Grade of Recommendation: WEAK } \\
\hline $\begin{array}{l}\text { R5 In all patients undergoing SCT with serum ferritin }>950 \mathrm{ng} / \mathrm{ml} \\
\text { pretransplant iron chelation should be done in order to reduce the } \\
\text { risk of VOD. }\end{array}$ & $\begin{array}{l}\text { Provided there is no need to proceed urgently to } \\
\text { SCT, Panel recommends against iron chelation } \\
\text { during conditioning regimens. }\end{array}$ & $7(5-8)$ & $27.78 \%$ \\
\hline $\begin{array}{l}\text { R6 All patients undergoing SCT with HBV-DNA positive or HBsAg } \\
\text { positive, are at increased risk of VOD. }\end{array}$ & & $7(6-8)$ & $33.33 \%$ \\
\hline
\end{tabular}




\begin{tabular}{|c|c|c|c|}
\hline $\begin{array}{l}\text { R7 All patients undergoing SCT with HCV RNA positivity are at } \\
\text { increased risk of VOD. }\end{array}$ & & $7(6-8)$ & $33.33 \%$ \\
\hline $\begin{array}{l}\text { R8 All patients undergoing SCT with pretransplant elevated } \\
\text { transaminases are at increased risk of VOD. }\end{array}$ & $\begin{array}{l}\text { The panel suggest a threshold value of } 2,5 \times \mathrm{UNL} \text {, } \\
\text { according to most prevalent experimental } \\
\text { protocols. }\end{array}$ & $7(6-7)$ & $16.67 \%$ \\
\hline $\begin{array}{l}\text { R9 In all patients undergoing SCT GVHD prophylaxis with combined } \\
\text { tacrolimus and sirolimus increases the risk of VOD, especially if } \\
\text { exposed to high sirolimus plasma levels. }\end{array}$ & & $7(5.75-8)$ & $38.89 \%$ \\
\hline $\begin{array}{l}\text { R13 In pediatric patients undergoing SCT at risk of VOD, Defibrotide } \\
6.25 \mathrm{mg} / \mathrm{kg} \text { every } 6 \text { hours in } 2 \text { hours ( } 25 \mathrm{mg} / \mathrm{kg} / \text { day) from } \\
\text { conditioning should be done in order to reduce VOD risk. }\end{array}$ & $\begin{array}{l}\text { 1. The dose of defibrotide recommended } \\
\text { comes from the only randomized phase III } \\
\text { trial present in literature. } \\
\text { 2. There drug has not been approved for this } \\
\text { indication. However, it is included in British } \\
\text { guideline. }\end{array}$ & $7(6-7)$ & $5.56 \%$ \\
\hline \multicolumn{4}{|l|}{ Uncertain (not approved) } \\
\hline $\begin{array}{l}\text { R12 In adult patients undergoing SCT at risk of VOD, the panel } \\
\text { cannot recommend in favor or against busulfan postponed after } \\
\text { cyclophosphamide during conditioning in order to reduce the risk of } \\
\text { VOD. }\end{array}$ & & $5(4-6)$ & $5.56 \%$ \\
\hline $\begin{array}{l}\text { R14 In adult patients undergoing SCT at high risk of VOD, the panel } \\
\text { cannot recommend in favor or against defibrotide in order to } \\
\text { reduce VOD risk. }\end{array}$ & $\begin{array}{l}\text { 1. Patients at risk of VOD, but not considered at } \\
\text { high risk: } \\
\text { - Represent an unexplored area } \\
\text { - There is an undergoing (NCT02851407) } \\
\text { randomized controlled trial comparing } \\
\text { defibrotide vs best supportive care in } \\
\text { patients 'at risk' and 'at high risk' of } \\
\text { VOD. Study is still recruiting. }\end{array}$ & $5(5-6)$ & $0 \%$ \\
\hline
\end{tabular}




\begin{tabular}{|c|c|c|c|}
\hline & $\begin{array}{l}\text { 2. Evidence is lacking in order to recommend a } \\
\text { specific dose and timing of Defibrotide } \\
\text { administration. } \\
\text { 3. The drug has not been approved for this } \\
\text { indication. }\end{array}$ & & \\
\hline $\begin{array}{l}\text { R15 High risk patients are defined as follow: at least } 1 \text { risk factor } \\
\text { with odds ratio }(\mathrm{OR}) \geq 10 \text {. }\end{array}$ & $\begin{array}{l}\text { The panel agree that the presence of more than } \\
\text { one risk factor is associated with the further } \\
\text { increase of VOD risk. However, the lack of a } \\
\text { validated score prevent from setting a threshold } \\
\text { for "high risk attribution". }\end{array}$ & $5.5(5-7)$ & $5.56 \%$ \\
\hline $\begin{array}{l}\text { R16 All patients undergoing SCT with }<15 \text { years old are at increased } \\
\text { risk of VOD. }\end{array}$ & & $4.5(2-7)$ & $0 \%$ \\
\hline $\begin{array}{l}\text { R17 All patients undergoing SCT with poor performance status } \\
\text { (ECOG } \geq 2 \text { ) are at increased risk of VOD. }\end{array}$ & & $6(3.75-7)$ & $11.11 \%$ \\
\hline $\begin{array}{l}\text { R18 Adults patients undergoing SCT are at higher risk of VOD when } \\
\text { busulfan-thiotepa is used in the conditioning regimen. }\end{array}$ & & $5(1-6)$ & $5.56 \%$ \\
\hline $\begin{array}{l}\text { R19 All patients undergoing SCT transplanted from a mismatched } \\
\text { donor are at increased risk of VOD. }\end{array}$ & & 6 (3-7.25) & $22.22 \%$ \\
\hline $\begin{array}{l}\text { R20 All patients undergoing SCT transplanted not in remission are at } \\
\text { increased risk of VOD. }\end{array}$ & & $7(4-8)$ & $27.78 \%$ \\
\hline $\begin{array}{l}\text { R21 In pediatric patients undergoing SCT the HPSE polymorphism } \\
\text { stratifies risk of VOD (genotype AA (at risk) vs GG or AG, genotype TT } \\
\text { (at risk) vs CC or CT). }\end{array}$ & & $5.5(5-7)$ & $0 \%$ \\
\hline $\begin{array}{l}\text { R22 All patients undergoing SCT are at higher risk of VOD if exposed } \\
\text { to high levels of CTX metabolites. }\end{array}$ & & $5(3-7)$ & $5.56 \%$ \\
\hline $\begin{array}{l}\text { R23 In all patients undergoing SCT the development of sepsis } \\
\text { increases the risk of VOD. }\end{array}$ & & $6(3.75-7)$ & $16.67 \%$ \\
\hline
\end{tabular}


R24 In all patients undergoing SCT, the panel cannot recommend in favor or against the use of sodium heparin or low molecular heparin for the VOD prophylaxis.
1. In this field there is a complete lack of evidence and wide variability in expert's opinions.

2. Sodium heparin or low molecular heparin, anyway, are still widely used in many BMT centers with the aim of preventing VOD. However, dose, timing and type of heparins largely varies among studies making interpretation of result difficult.

3. There is no evidence of efficacy in VOD prophylaxis for glutamine, FFP, antithrombin III, heparin and PGE1.

\begin{tabular}{|l|l|}
\hline 2.5 (1-4.25) & $5.56 \%$ \\
& \\
& \\
\hline $4(2-5)$ & \\
\hline $4(2-5)$ & $0 \%$ \\
\hline
\end{tabular}

Table S4: Recommendations on VOD risk and prophylaxis. 


\section{DIAGNOSIS}

\begin{tabular}{|l|l|l|}
\hline Strong & Notes & Median (IQR) \\
agreement (\%)
\end{tabular}

\section{Grade of Recommendation: STRONG}

D1 For adult patients undergoing SCT in the first 21 days post-SCT for the diagnosis of VOD the following criteria must be fulfilled:

Bilirubin $\geq 2 \mathrm{mg} / \mathrm{dL}$

And at least 2 of the following:

-painful hepatomegaly clinically evident

-unexplained weight gain $>5 \%$ compared to baseline value -ascites above baseline value.

D2 For pediatric patients undergoing SCT, 2 or more of the following criteria must be used for the diagnosis of VOD:

-unexplained consumptive and transfusion-refractory

thrombocytopenia

-otherwise unexplained weight gain on 3 consecutive days despite the use of diuretics or a weight gain $5 \%$ above baseline value

-hepatomegaly above baseline value

-ascites above baseline value

-rising bilirubin from a baseline value on 3 consecutive days or bilirubin $\geq 2 \mathrm{mg} / \mathrm{dl}$ (after the exclusion of competing causes).

D4 In all patients undergoing SCT, in case of persistent suspicion of VOD, the presence of a histological or an instrumental evidence suggestive for VOD should be used for the diagnosis of VOD.

D5 All patients undergoing SCT the daily assessment of the symptoms and signs (pain in upper right quadrant, hepatomegaly, weight gain, abdomen enlargement) must be registered in clinical records.

\begin{tabular}{|c|c|c|}
\hline Ascites should be confirmed by imaging. & $9(8.75-9)$ & $94.44 \%$ \\
\hline $\begin{array}{l}\text { 1. Hepatomegaly and ascites should be } \\
\text { confirmed by imaging. }\end{array}$ & $9(8-9)$ & $94.44 \%$ \\
\hline $\begin{array}{l}\text { 1. Suspicion of VOD: diagnostic criteria not } \\
\text { completely satisfied and at least } 1 \text { of the } \\
\text { classical criteria for adult patients D1 or } 1 \text { of } \\
\text { the criteria for pediatric patients D2. } \\
\text { 2. The panel has identified ultrasound imaging } \\
\text { and hepatic venous pressure gradient (HVPG) } \\
\geq 15 \mathrm{mmHg} \text { as diagnostic tools. } \\
\text { 3. For ultrasound imaging interpretation refer } \\
\text { to D5. }\end{array}$ & $8(7-9)$ & $66.67 \%$ \\
\hline & $9(9-9)$ & $100 \%$ \\
\hline
\end{tabular}


D6 In all patients undergoing SCT with suspected VOD an ultrasound exam is recommended in order to assess the presence of:

-hepatomegaly

-ascites

-decrease in velocity or reversal of the portal flow

-recanalization of the umbilical vein

-gall bladder wall thickening.

D7 In adult patients undergoing SCT with suspicion of VOD, particularly in case of late onset VOD, a liver biopsy is recommended for the diagnosis of VOD.

D8 In case of liver biopsy is indicated, in adult patients transjugular liver biopsy should be preferred.

D9 In case of liver biopsy is indicated, in pediatric patients transjugular liver biopsy should be avoided.
1. Suspicion of VOD: diagnostic criteria not completely satisfied and at least 1 of the classical criteria for adult patients D1 or 1 of the criteria for pediatric patients D2

2. The panel considers the presence of recanalization of the umbilical vein and/or reversal of the portal flow as a strong element of suspicious.

1. Suspicion of VOD: diagnostic criteria not completely satisfied and at least 1 of the classical criteria for adult patients $\mathbf{D} 1$.

2. $\mathrm{VOD} / \mathrm{SOS}$ is confirmed by liver biopsies showing classical features including reticulin deposition within sinusoids, central vein occlusions, hepatocyte atrophy/ necrosis, sinusoidal/perivenular hemorrhage, and sparing of portal tracts.

3. Biopsy is recommended only in well-trained centers.

A skilled team is needed in order to reduce procedure related risk.

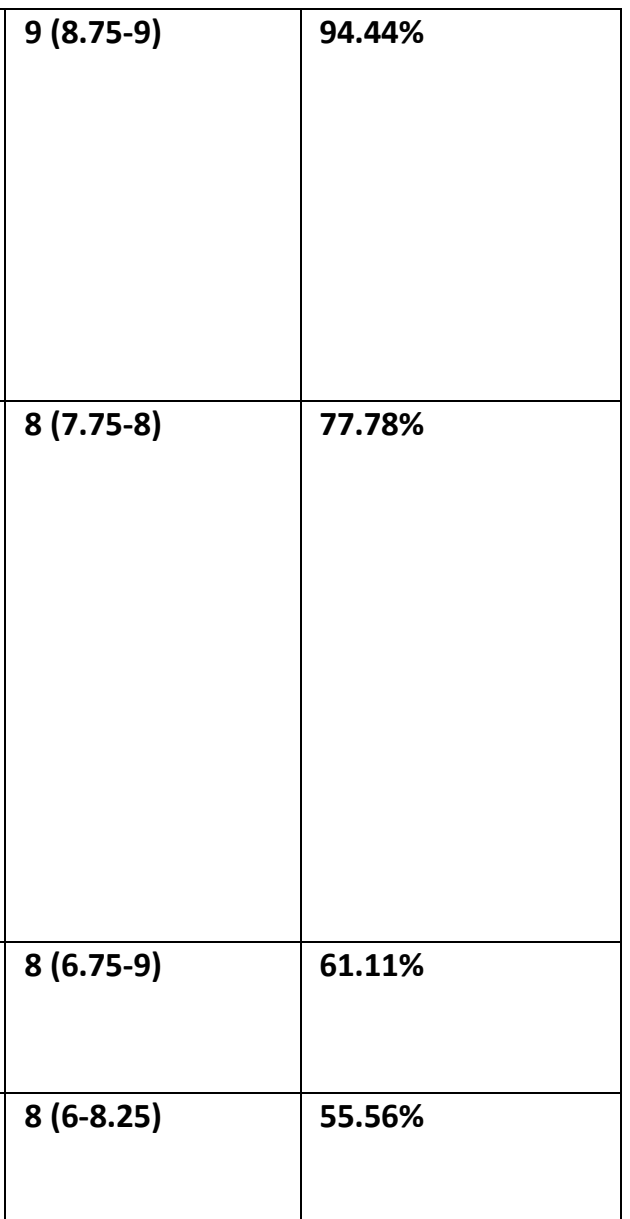

Grade of Recommendation: WEAK

D3 In adult patients undergoing SCT after 21 days post-SCT for the diagnosis of late onset VOD the same classical criteria can be used (see recommendation $\mathbf{D} \mathbf{1}$ ).

\section{Uncertain (not approved)}

$7.5(5-8.25)$

$50 \%$ 


\begin{tabular}{|c|c|c|c|}
\hline $\begin{array}{l}\text { D10 In all patients undergoing SCT the panel cannot recommend in } \\
\text { favour or against the use of fibroscan (measurement of liver stiffness), } \\
\text { MR imaging or TC imaging (evaluation of hepatic features particularly } \\
\text { ascites, periportal edema, narrow right hepatic vein) for the diagnosis } \\
\text { of VOD. }\end{array}$ & $\begin{array}{l}\text { In this field there is a complete lack of evidence } \\
\text { and wide variability in expert's opinions. }\end{array}$ & $4.5(3.75-6.5)$ & $22.22 \%$ \\
\hline \multicolumn{4}{|l|}{ WEAK Disagree (Rejected) } \\
\hline $\begin{array}{l}\text { D11 In all patients undergoing SCT the use of the endothelial damage } \\
\text { markers or biomarkers measurement (ST2, ANG2, L-Ficolin, HA, } \\
\text { VCAM1) is not recommended for the diagnosis of VOD. }\end{array}$ & In this field there is lack of evidence. & $4(3-5)$ & $5.56 \%$ \\
\hline $\begin{array}{l}\text { D12 In all patients undergoing SCT the plasmatic BNP measurement is } \\
\text { not recommended for the diagnosis of VOD. }\end{array}$ & $\begin{array}{l}\text { One clinical study does not recommend the use of } \\
\text { plasmatic BNP measurement. }\end{array}$ & $3.5(2-5)$ & $0 \%$ \\
\hline
\end{tabular}

Table S5: Recommendations on VOD diagnosis. 


\begin{tabular}{|c|c|c|c|}
\hline \multicolumn{4}{|c|}{ TREATMENT } \\
\hline & Notes & Median (IQR) & \begin{tabular}{|l|} 
Strong \\
agreement (\%)
\end{tabular} \\
\hline \multicolumn{4}{|l|}{ Grade of Recommendation: STRONG } \\
\hline $\begin{array}{l}\text { T1 In all patients with a diagnosis of severe VOD with or without } \\
\text { multiorgan failure post-SCT, treatment with defibrotide as soon as } \\
\text { possible is recommended in order to reduce mortality. }\end{array}$ & Severe VOD is defined according to EBMT criteria. & $9(8-9)$ & $88.89 \%$ \\
\hline $\begin{array}{l}\text { T2 In all patients with a diagnosis of severe VOD with or without } \\
\text { multiorgan failure post-SCT, treatment with defibrotide } 25 \mathrm{mg} / \mathrm{kg} / \mathrm{d} \text { for } \\
\text { at least } 21 \text { days and anyway till resolution of signs and symptoms of } \\
\text { severe VOD is recommended in order to reduce mortality related to } \\
\text { veno-occlusive disease. }\end{array}$ & & $9(8-9)$ & $83.33 \%$ \\
\hline $\begin{array}{l}\text { T3 In all patients with a diagnosis of severe VOD with or without } \\
\text { multiorgan failure post-SCT receiving defibrotide a careful monitoring } \\
\text { for increased hemorrhagic risk is indicated in order to institute a } \\
\text { prompt treatment of eventual hemorrhagic complications. }\end{array}$ & $\begin{array}{l}\text { 1. Active medical (full blood count on a daily } \\
\text { basis) and nursing surveillance (vital signs, } \\
\text { skin observation, stool observation) for } \\
\text { hemorrhages should be instituted and } \\
\text { registered in clinical records. } \\
\text { 2. A detailed protocol for a patients monitoring } \\
\text { may be developed according to Botti S et al } \\
\text { "Veno-occlusive disease nurse management: } \\
\text { development of the dynamic monitoring tool } \\
\text { by the GITMO nursing group" Ecancer 2016, } \\
\text { 10: } 661 \text { DOI: } 10.3332 / \text { ecancar.2016.661 }\end{array}$ & 9 (7.75-9) & $77.78 \%$ \\
\hline $\begin{array}{l}\text { T4 In all patients with a diagnosis of severe VOD with or without } \\
\text { multiorgan failure post-SCT receiving defibrotide, coadministration of } \\
\text { drugs increasing the bleeding risk (antiaggregant therapy, } \\
\text { anticoagulant therapy at prophylactic or therapeutic dose) must be } \\
\text { avoided. }\end{array}$ & & $8.5(8-9)$ & $88.89 \%$ \\
\hline
\end{tabular}


T5 In all patients developing VOD post-SCT, fluid restriction and diuretics, aiming for equal or negative fluid balance, is recommended in order to reduce the risk of progression to severe VOD, MOF or mortality related to VOD.

T6 The panel acknowledge the importance of supportive therapy in order to reduce symptoms (eg, pain, dyspnea, fluid retention, psicological stress.). This is a high priority topic for future clinical research.

\section{Grade of Recommendation: WEAK}

T7 In all patients developing VOD post-SCT, with renal failure (AKI) or symptomatic fluid overload nonresponsive to diuretic therapy, continuous hemodialysis ( $\mathrm{CVVH}$ ) should be done in order to reduce the risk of progression to severe VOD, MOF or mortality related to VOD.

T8 In all patients developing VOD post-SCT, ursodeoxycholic acid administration at the daily dose of $10-15 \mathrm{mg} / \mathrm{kg}$ should be done in order to reduce the risk of progression to severe VOD, MOF, or mortality related to VOD.

\section{Uncertain (not approved)}

T9 Higher efficacy is expected from treatment with defibrotide in pediatric patients. plasma in all patients developing VOD post-SCT in order to reduce the risk of progression to severe VOD, MOF, or mortality related to VOD.

T11 The panel cannot recommend for or against the avoidance of calcineurin inhibitors in all patients developing VOD post-SCT in order to reduce endothelial damage.

T12 The panel cannot recommend for or against the use of albumin infusion in all patients developing VOD post-SCT in order to reduce the risk of progression to severe VOD and MOF.

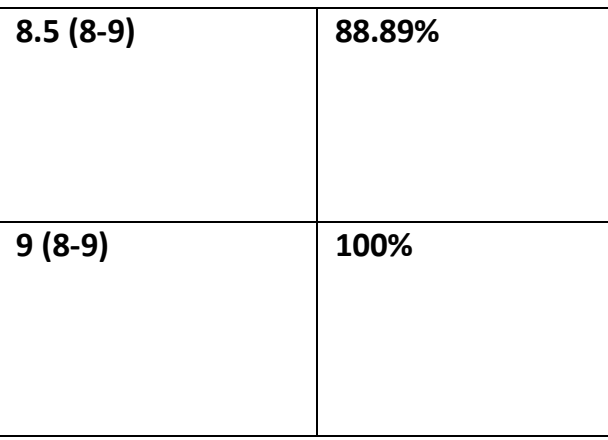

\begin{tabular}{|l|l|l|}
\hline & \\
\hline & \\
\hline & \\
\hline
\end{tabular}

\begin{tabular}{|l|l|} 
& $7(6-8)$ \\
\hline $6.5(5.75-8)$
\end{tabular}

$38.89 \%$

$27.78 \%$

Characteristics of the population, intervention 6 (4.75-8) and outcome are the same as for the recommendation $\mathbf{T 2}$

\begin{tabular}{|l|} 
\\
\hline $\begin{array}{l}\text { In these fields there is a complete lack of evidence } \\
\text { and wide variability in expert's opinions. }\end{array}$
\end{tabular}

\begin{tabular}{|l|l|}
\hline $5(5-6)$ & $5.56 \%$ \\
\hline $5(4-6.25)$ & $11.11 \%$ \\
\hline $5(4-6.25)$ & $5.56 \%$ \\
\hline
\end{tabular}




\begin{tabular}{|c|c|c|c|}
\hline $\begin{array}{l}\text { T13 The panel cannot recommend for or against the use of high dose } \\
\text { steroids in all patients developing VOD post-SCT in order to reduce the } \\
\text { risk of progression to severe VOD, MOF or mortality related to VOD. }\end{array}$ & $\begin{array}{l}\text { In these fields there is a complete lack of evidence } \\
\text { and wide variability in expert's opinions. }\end{array}$ & $5(2.75-6)$ & $0 \%$ \\
\hline \multicolumn{4}{|l|}{ WEAK Disagree (Rejected) } \\
\hline $\begin{array}{l}\text { T14 In all patients developing VOD post-SCT, human soluble } \\
\text { thrombomodulin is not recommended in order to reduce the risk of } \\
\text { progression to severe VOD, MOF, or mortality related to VOD. }\end{array}$ & $\begin{array}{l}\text { In these fields there is a complete lack of evidence } \\
\text { and wide variability in expert's opinions. }\end{array}$ & $4(2.75-5)$ & $0 \%$ \\
\hline $\begin{array}{l}\text { T15 In all patients developing VOD post-SCT, LMWH is not } \\
\text { recommended in order to reduce the risk of progression to severe VOD, } \\
\text { MOF, or mortality. }\end{array}$ & & $3(2-5)$ & $0 \%$ \\
\hline $\begin{array}{l}\text { T16 In all patients developing VOD post-SCT, transjugular intrahepatic } \\
\text { portosystemic shunting (TIPS) is not recommended in order to reduce } \\
\text { the risk of progression to severe VOD, MOF, or mortality. }\end{array}$ & $\begin{array}{l}\text { In these fields there is a complete lack of evidence } \\
\text { and wide variability in expert's opinions. }\end{array}$ & $3(3-5)$ & $0 \%$ \\
\hline \multicolumn{4}{|l|}{ STRONG Disagree (Rejected) } \\
\hline $\begin{array}{l}\text { T17 In all patients developing VOD post-SCT, treatment with } \\
\text { recombinant human tissue plasminogen activator (rt-PA) is not } \\
\text { recommended in order to reduce the risk of progression to severe VOD, } \\
\text { MOF, or mortality related to VOD. }\end{array}$ & $\begin{array}{l}\text { rt-PA is associated with a high bleeding risk, } \\
\text { especially at dosages }>10 \mathrm{mg} / \text { daily or in } \\
\text { combination with heparin. }\end{array}$ & $2(2-2.25)$ & $0 \%$ \\
\hline
\end{tabular}

Table S6: Recommendations on VOD treatment. 